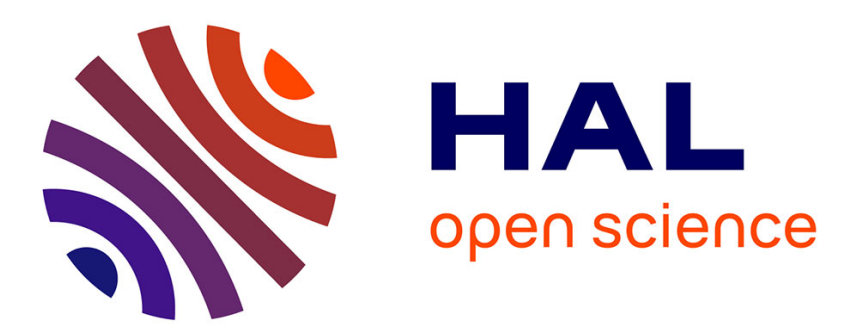

\title{
Detailed mapping of a mantle diapir below a paleo-spreading center in the Oman ophiolite
}

David Jousselin, Adolphe Nicolas, Francoise Boudier

\section{To cite this version:}

David Jousselin, Adolphe Nicolas, Francoise Boudier. Detailed mapping of a mantle diapir below a paleo-spreading center in the Oman ophiolite. Journal of Geophysical Research : Solid Earth, 1998, 103 (B8), pp.18153-18170. 10.1029/98JB01493 . hal-02374869

\section{HAL Id: hal-02374869 \\ https://hal.science/hal-02374869}

Submitted on 21 Nov 2019

HAL is a multi-disciplinary open access archive for the deposit and dissemination of scientific research documents, whether they are published or not. The documents may come from teaching and research institutions in France or abroad, or from public or private research centers.
L'archive ouverte pluridisciplinaire HAL, est destinée au dépôt et à la diffusion de documents scientifiques de niveau recherche, publiés ou non, émanant des établissements d'enseignement et de recherche français ou étrangers, des laboratoires publics ou privés. 


\title{
Detailed mapping of a mantle diapir below a paleo-spreading center in the Oman ophiolite
}

\author{
David Jousselin, Adolphe Nicolas and Françoise Boudier \\ Laboratoire de Tectonophysique, Centre National de Recherche Scıentıfique, ISTEEM, Université Montpellier II \\ Montpellier, France
}

\begin{abstract}
Detailed mapping of the well-exposed Maqsad area in the Oman ophiolite addresses the question of accretion mechanisms at oceanic ridges. Steep peridotite lineations are interpreted as a three-dimensional mantle diapir below a paleo-fast spreading ridge. The uppermost part of the diapir reveals three heads coverng $100 \mathrm{~km}^{2}$ in area. The main head $\left(30 \mathrm{~km}^{2}\right)$ displays warped vertical foliation trajectories. Cross sections show that the vertical flow rotated to the horizontal below the Moho within a 500-m-thick melt-impregnated transition zone. Penetrative structures dip outward from the djapir. and the Moho bulges upward several hundred meters above this area. The ridge axis is ascribed to a $1-$ to $3-\mathrm{km}$ wide-corridor of lineations parallel to the sheeted dike trend, which crosses the main diapir head. Mass balance calculations show that this diapir could account for the formation of a $25-\mathrm{km}$-long crustal segment, provided that the upward flow velocity is $\approx 10$ times the ridge spreading rate. The narrow' space left for the horizontal flow at the outskirts of the diapir implies active divergent flow from the diapir center with velocities 1 order of magnitude faster than the spreading rate. Accordingly. the horizontal foliations display the strongest fabrics. The calculations predict that the diverging flow should become passıve $10 \mathrm{~km}$ past the diapir limits, as suggested by field data. The mechanisms makung possible the sharp flow rotation at the top of the diapir are discussed.
\end{abstract}

\section{Introduction}

Since the discovery of mantle diapirs in ophiolitic peridotites [Nicolas and Violette 1982] the presence of diapirs beneath oceanic ridge segments has been proposed to explain ridge discontinuities [Crane, 1985; Whitehead et al., 1984] and the focusing of magmatic and tectonic activity within a few kilometers on either side of a ridge [Buck and $S u, 1989$; Rabinowicz et al., 1984; Scott and Stevenson, 1989; Sotin and Parmentier, 1989]. Diapirs a few tens of kilometers in diameter seem consistent with the large and circular mantle Bouguer anomalies recorded at slow spreading ridges [Kuo and Forsyth, 1988; Lin et al., 1990; Tolstoy et al., 1993]. On the other hand, the fast spreading East Pacific Rise (EPR) is associated with smooth topography and much smaller variation in along-axis mantle Bouguer anomalies. How the mantle contributes to gravity anomalies is still under discussion [Cormier et al., 1995; Madsen et al., 1990; Magde et al., 1995; Wilson, 1992], and two main models of mantle upwelling below fast spreading ridges have been proposed. Continuous upwelling along strike (two dimensional (2-D) model) has been advanced by Lin and Phipps Morgan [1992], Parmentier and Phipps Morgan [1990], Sparks et al. [1993], and Barnoin-Jha et al. [1997] to explain the attenuated gravimetric signal at the EPR, as well as the less abrupt segmentation that occurs at slow spreading ridges. In these models the topography and gravity variations reflect only crustal features. Alternatively, a focused 3-D mantle flow model has been developed by combining the gravity data [Wang and

Copyright 1998 by the American Geophysical Union.

Paper number 98JB01493.

0148-0227/98/98JB-01493\$09.00
Cochran, 1993] with a new analysis of seismic reflection data [Barth and Mutter, 1996; Wang et al., 1996]. In this model the EPR is fed by mantle diapirs, no larger than $20 \mathrm{~km}$ across, which are located in the central part of ridge segments and which are associated with local thinning of the crust. This question remains open because geophysical techniques still lack the necessary resolution to map patterns of mantle flow and melt production below ridges.

Another approach to this question is to map ophiolites and their mantle structures. Several studies have concluded that the Oman ophiolite, originally part of the Neothethys seafloor, was similar to fast spreading ridges, mainly because of its continuous magmatically deformed gabbro section [e.g., Boudier and Nicolas, 1985; MacLeod and Rothery, 1992; Nicolas, 1989; Tilton et al., 1981]. An accurate reconstruction of the paleospreading geometry has been possible in the Oman ophiolite because of its excellent exposures where a record of hightemperature and ridge-related tectonic activity is preserved [e.g., Nicolas et al., 1988a; Boudier et al., 1997]. Initiation of obduction by oceanic detachment occurred at, or very close to, the ridge. This has been shown by the conclusions of (1) structural analysis showing that detachment occurred in a hot and locally active lithosphere [Boudier et al., 1988, 1997] and (2) radiometric dating showing that there is no significant age difference between the last stages of magmatic activity at the ridge and the first detachment-related basal metamorphism [Hacker, 1994; Montigny et al., 1988]. Systematic structural mapping over the southern half of the Oman ophiolite has revealed a paleoridge organization that resembles an EPR microplate forming in superfast spreading conditions [Boudier et al., 1997]. This situation may explain why spreading centers have been fossilized within the ophiolite. We identified several areas of steep lineations and interpreted them as mantle diapirs 
underlying the paleo-ridge axis [Nicolas, 1989; Nicolas and Boudier, 1995; Nicolas et al., 1988a]. The best example has been found in the Maqsad area [Ceuleneer, 1986; Ceuleneer et al., 1988; Nicolas and Boudier, 1995; Rabinowicz et al., 1987], the focus of this study, which represents the central part of a segment that was created by a large propagator that was active at the initiation of oceanic thrusting. Ceuleneer [1991] and Ceuleneer and Rabinowicz [1992] found a dominant azimuth of steep foliations parallel to the ridge in contradiction with a narrow pipe-like axial upwelling picture. Still they found radial lineations. They equated the ridge axis with a dunite horizon that contains a local area of weak deformation and also separates westward and eastward shear senses in horizontal foliations. Finally, they claimed that dikes are restricted to the periphery of the upwelling. Following further structural study of the area, Nicolas and Boudier [1995] used new criteria to locate the ridge axis and concluded that the patterns of foliation trajectories are better fitted by a pipe-like model.

To address the important issue of mantle flow below a ridge axis, we undertook new mapping of this Maqsad area, the most suitable in the Oman ophiolite and possibly in the world. This study extends beyond the previous ones in three respects: (1) The scale of structural mapping of dikes, foliations, and lineations is finer, with 230 new field stations, in addition to the 310 previous ones; the scale of mapping now corresponds to one field station every $100 \mathrm{~m}$ in the areas where highly variable foliation and lineation directions are observed. (2) The mantle deformation and its anisotropy are quantified by using 16 crystallographic fabric measurements and a systematic comparison with 250 new thin sections. (3) The problem of the rotation from vertical to horizontal flow in mantle peridotites has been specially addressed in five detailed cross sections. Other cross sections allowed us to specify the variations in thickness of the Moho transition zone in areas of upward flow. Estimations of mantle flow velocities are also deduced from these cross sections. Assuming they apply to fast spreading ridges such as the EPR, our conclusions should help to orient future geophysical campaigns aimed at understanding ridge segmentation and upwelling dynamics in fast spreading ridges.

\section{Structural Methods}

Since the principles of structural analysis in ophiolites with special references to peridotites have been previously presented [Nicolas, 1989], we recall only the basis of our method.

\subsection{Reference Frame}

First, one needs to determine the paleohorizontal and the direction of the paleoridge axis. To determine a paleohorizontal, we assume that the contact between mantle peridotites and the crustal section (paleo-Moho) was approximately horizontal and that the sheeted dike complex was vertical. We also assume that the ridge trend is parallel to the sheeted dike complex; this hypothesis is confirmed by observations in fracture zones [Auzende et al., 1989].

\subsection{Analysis of Flow Structures in the Mantle Section}

Several measurements of foliations and lineations in the peridotites are made at every field station, and at least one oriented sample is taken. In the laboratory, field measurements are checked on bleached and saw-cut samples. The foliation plane corresponds to the plane of mineral flattening, which is the $X, Y$ plane of the strain ellipsoid. A mineral or mineral aggregate lineation is usually parallel to $X$, the long axis of the strain ellipsoid. Foliations and lineations are represented in maps by individual measurements and by their trajectories. In areas of flat lying foliations the foliation trajectory map is a poor representation, and in contrast, the lineation map is most informative; the opposite is true when foliations and lineations are steep.

The analysis of plastic flow structures in thin sections has two purposes: (1) constraining qualitatively the temperature of deformation from textures and (2) deducing the flow geometry from the fabrics (kinematic analysis). High- $T$ deformation $\left(1200^{\circ}-1250^{\circ} \mathrm{C}\right)$ [Nicolas and Poirier, 1976], ascribed to asthenospheric flow, is characterised by coarse grained structures with well-recovered substructures; low- $T$ deformation, ascribed to lithospheric flow, $\left(1100^{\circ} \mathrm{C}\right)$ is reflected by porphyroclastic structures, with a varying recrystallization in fine-grained neoblasts. Kinematic analysis relies on relating crystal shape to the lattice fabric. Because of the large shear strain commonly experienced by the peridotites, foliations and lineations have only a slight obliquity with the flow plane and the flow line, respectively [Nicolas and Poirier, 1976]. This obliquity allows us to determine the shear sense, but for the sake of simplicity we consider that the flow planes and the foliations are subparallel.

\section{The Sumail Massif}

The Maqsad area belongs to the Sumail massif, an area about $70 \mathrm{~km}$ long and $30 \mathrm{~km}$ wide between the Jebel Akhdar to the west and the Saih Hatat to the northeast (Figure 1). The eastern structures of this massif are contiguous with those of the adjacent Wadi Tayin massif to the SE, especially the dike trajectories [Boudier et al., 1997]. This contiguity shows that no significant relative displacement has taken place along NNE-SSW Wadi Andam, which separates the two massifs. The west side of the Maqsad district (16X22 km) is bounded by the high-T Muqbariah shear zone, beyond which a structurally distinct mantle formation is observed [Beurrier, 1987; Ceuleneer, 1991; Nicolas and Boudier, 1995].

Several studies recognize the Maqsad area as the spreading ridge that formed at least a part of the Sumail massif, mainly because of the occurrence of steep peridotite lineations [Boudier et al., 1997; Ceuleneer, 1991; Ceuleneer et al., 1996; Ceuleneer and Rabinowicz, 1992; Nicolas and Boudier, 1995] and the structural continuity, at the scale of several tens of kilometers, of the flow structures, which is incompatible with off-axis features such as a mantle diapir feeding a seamount [Nicolas and Boudier, 1995]. One of the most remarkable features of the Maqsad district is a local thick Moho transition zone between the harzburgitic mantle and a continuous gabbro section. This transition zone is composed of pure dunites interlayered with plagioclase- and clinopyroxene-impregnated dunites, gabbro lenses, and relics of harzburgite; it represents a level of magmatic exchange between the asthenospheric mantle and the accreting crust [Boudier and Nicolas, 1995]. The dunite formed in situ by dissolution of the orthopyroxenes by the circulating melt [Cassard et al., 1981; Kelemen, 1990; Leblanc et al., 1980; Loomis and Gottschalk, 1981; Nicolas and Prinzhofer, 1983; Sinton, 1977]. Some of this percolating melt crystallized diopside and plagioclase beads in the dunite matrix. The transition zone thickness varies from a few meters in rare places to a maximum of $500 \mathrm{~m}$ (see cross sections and maps presented further below). Similar thick transition zones, elsewhere in the Oman ophiolite, are always overlying regions of 


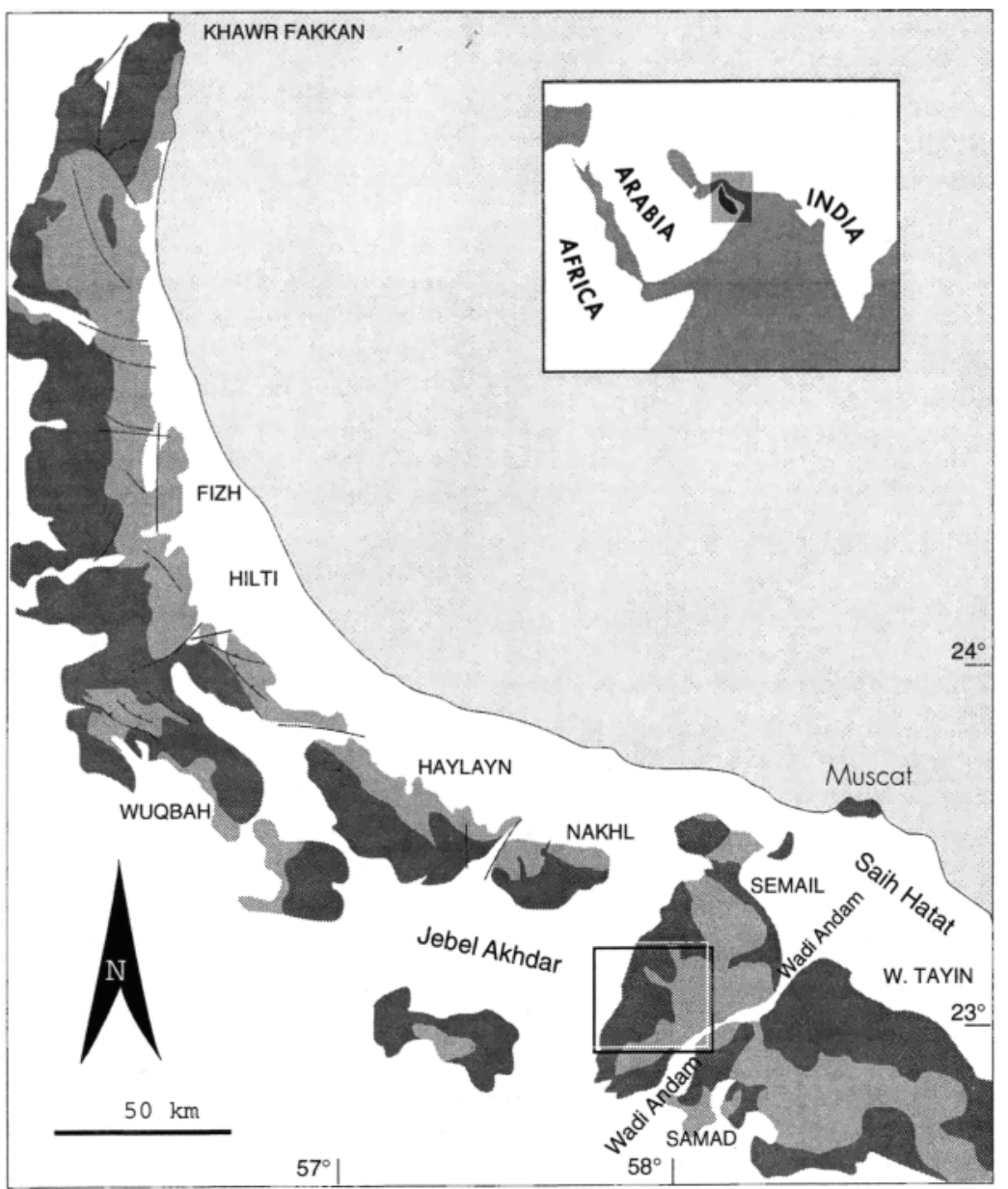

Figure 1. Simplified map of the Oman ophiolite. The box is the location of the studied area. Light gray, crustal section; dark gray, mantle section.

vertical mantle flow [Boudier and Nicolas, 1995]. The crustal section in the Maqsad area is remarkably rich in wehrlite intrusions, making it sometimes difficult to locate the Moho with precision.

Most of the ophiolite is rather continuous along its $500-\mathrm{km}$ length, and paleomagnetic data [Perrin et al., 1994; Thomas et al., 1988] show that all massifs were emplaced as a single block with limited internal rotation. In several publications it has been stressed that distinguishing ridge structures from younger ones was possible considering the temperature at which they have been formed [e.g., Nicolas, 1989; Nicolas and Boudier, 1995]. With this consideration in mind it can be proved that most folds observed in the gabbro unit have been formed below the ridge and that faults are indeed ridge-related hydrothermal veins. A spectacular example lies in a gabbro outcrop near Mahram (Figure 2), where the Moho remains subhorizontal, and it can be checked directly in the field and in thin sections that microstructures are magmatic, even those at the contact between discordant layers. This finding shows that this deformation is ridge related. Similarly, faults mapped by aerial photographs, which are often parallel to the sheeted dike complex orientation, are shown in the field to be hydrothermal veins with limited displacement.

The Sumail and Wadi Tayin massifs occupy a 100-km-across synform basin beween the Jebel Akhdar and the Saih Hatat autochtonous domes, as confirmed by the shape of the basement imaged by gravimetric maps and modeling [Ravaut et al., 1997]. These autochtonous domes, which have $3 \mathrm{~km}$ of relief, have tilted the ophiolite massifs during their Cenozoic uplift. This deformation is not at the local scale $(10-20 \mathrm{~km})$ considered here and should not affect the locally observed flat lying crustal structure. Harzburgites crop out in the NW part of the Sumail massif, and upper gabbros and sheeted dike complex crop out in the south and SE, suggesting that the massif has a slight tilt to the SE. The Moho near Maqsad is located at various elevations and presents variable orientations from $80^{\circ} \mathrm{S} 35^{\circ}$ (azimuth, dip direction, dip) in the south to $0^{\circ} \mathrm{E} 15^{\circ}$ in the east, warping around an area of steep lineations, as will be presented in section 5 . Considering (1) the thickness of the Sumail massif (up to $7 \mathrm{~km}$ ) [Ravaut et al., 1997] which should make it difficult to be

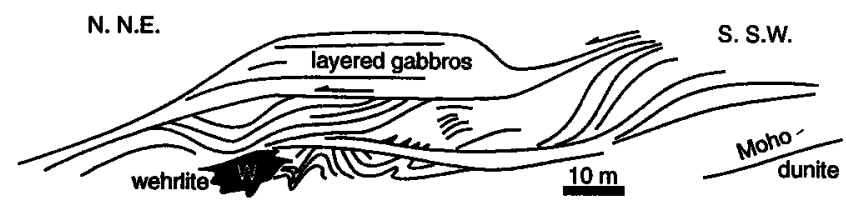

Figure 2. Drawing of a gabbro outcrop in the Maqsad area. This outcrop is situated $1 \mathrm{~km} \mathrm{NE}$ of Mahram. It is exceptional for its complex magmatic deformation. 
disrupted during and after emplacement, (2) the near-vertical attitude of dikes, and (3) the absence of evidence for any internal tectonic rotation, we conclude that these orientations are not due to the obduction or Cenozoic uplift, but rather that the Moho was not strictly horizontal at the spreading ridge. These orientations could be a record of fluctuations of the Moho level at the ridge axis as proposed by Nicolas et al. [1996] and Barth and Mutter [1996]. If this is correct, it is difficult to give a precise measurement of the general tilt $\left(\leq 10^{\circ}\right)$ of the Sumail massif at the Maqsad area. Because all measurements of the paleo-Moho are nearly horizontal, it is possible to get a fair idea of the flow orientation by simply looking at the maps.

\section{Dike Pattern}

The diabase sheeted dike complex is best exposed in Wadi Andam about $15 \mathrm{~km}$ SE of the village of Maqsad, where it has an average orientation of $140^{\circ} \mathrm{N} 80$ [MacLeod and Rothery, 1992; Nicolas and Boudier, 1995]. Following previous studies [Ceuleneer, 1991; Ceuleneer et al., 1996; Nicolas, 1989; Nicolas et al., 1994], we have measured numerous dikes of various natures in the mantle section (Figures 3 and 4). Depending on the temperature of the host mantle rocks when they were injected, these dikes range from diabases with no chilled margins to coarse-grained gabbros locally rimmed by a dunite reaction zone. The average dike orientation is constant, whatever the dike facies, implying that in this region the stress field remained constant during cooling from $1200^{\circ} \mathrm{C}$ to $700^{\circ} \mathrm{C}$, the host rock temperature estimated for diabase dikes without chilled margins. In agreement with Ceuleneer's [1986] map, but in contradiction with his more recent one [Ceuleneer, 1996], we could not find any large area devoid of dikes, in particular in the area of upward mantle flow (see next section). The average dike orientation swings from an orientation near $160^{\circ}$ in the western part of the massif to an orientation near $110^{\circ}$ in its eastern part (Figure 3 ).

\section{Structural Maps}

The shape of the Maqsad diapir is best revealed by contouring isodips of steep foliations and lineations. These isodips define three distinct closely spaced areas (Figure 5). The main area of steep lineations is triangle shaped and covers $30 \mathrm{~km}^{2}$ south of the village of Maqsad (Figures 5a and 6b). It includes 77 steep peridotite lineations, from a few meters, down to $600 \mathrm{~m}$ below the Moho. Locally, we observe at the margin of this main diapir that the steep structures cross cut the harzburgite-dunite horizon and continue into the dunite until a sharp rotation occurs very near below the Moho. The sharp rotation is illustrated by closely spaced isodips in the Moho transition zone (Figure $5 b$ ) and by the cross sections presented below.

Within this diapiric area, steep foliation trajectories warp around the main upwelling zone, with a sharp closure in the northern end. The stereonet of the steep dipping foliations (Figure 6a) illustrates these orientations, with only $40 \%$ of the foliations subparallel to the ridge trend $\left(140^{\circ} \pm 30^{\circ}\right)$. Further northwest, some foliations remain steep with azimuths parallel to the ridge trend, but they do not belong to the diapir because they carry horizontal lineations. Away from the diapir, subhorizontal foliations vary in orientation, a majority dipping to the west on the western side of the diapir and to the east on the eastern side.

Horizontal lineations are slightly divergıng from this diapir center, especially on the west side of Wadi Kurah where they rotate from a direction parallel to the NW-SE dike trend to an EW direction with a moderate plunge westward (Figure $6 \mathrm{c}$ ). This divergence is not present on the eastern side, where there is an abrupt change from lineations parallel to the ridge trend to a homogeneous E-W flow, plunging on average eastward (Figure 6d).

Two outliers that include more than 10 steep lineation measurements, each within less than $10 \mathrm{~km}^{2}$ in area, are found a few kilometers north on each side of the ridge. These steep lineations are observed across the limit between harzburgites and
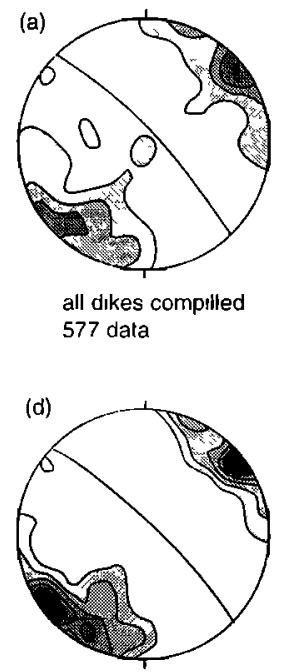

dikes from the central zone 241 data

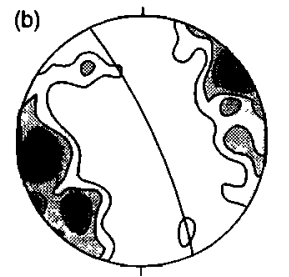

dikes from the West flank 157 data

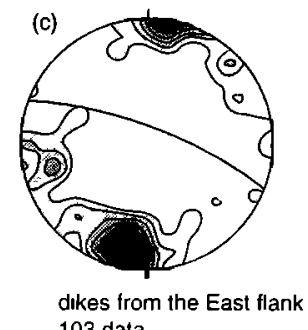

103 data

Figure 3. Stereonets of dike intrusions. Lower hemisphere stereographic projections of poles to dikes. (a) All dikes (contours at $0.5 \%, 1 \%, 2 \%, 4 \%, 8 \%$, and 16\%); (b), (c), dikes at the SW and NE of the "central zone" (between dotted lines on Figure 4) (contours at $1 \%, 2 \%, 4 \%, 8 \%$, and $16 \%$ ); respectively; and (d) dikes of the "central zone" (contours at $0.5 \%, 1 \%, 2 \%, 4 \%, 8 \%$, and $16 \%$ ). 


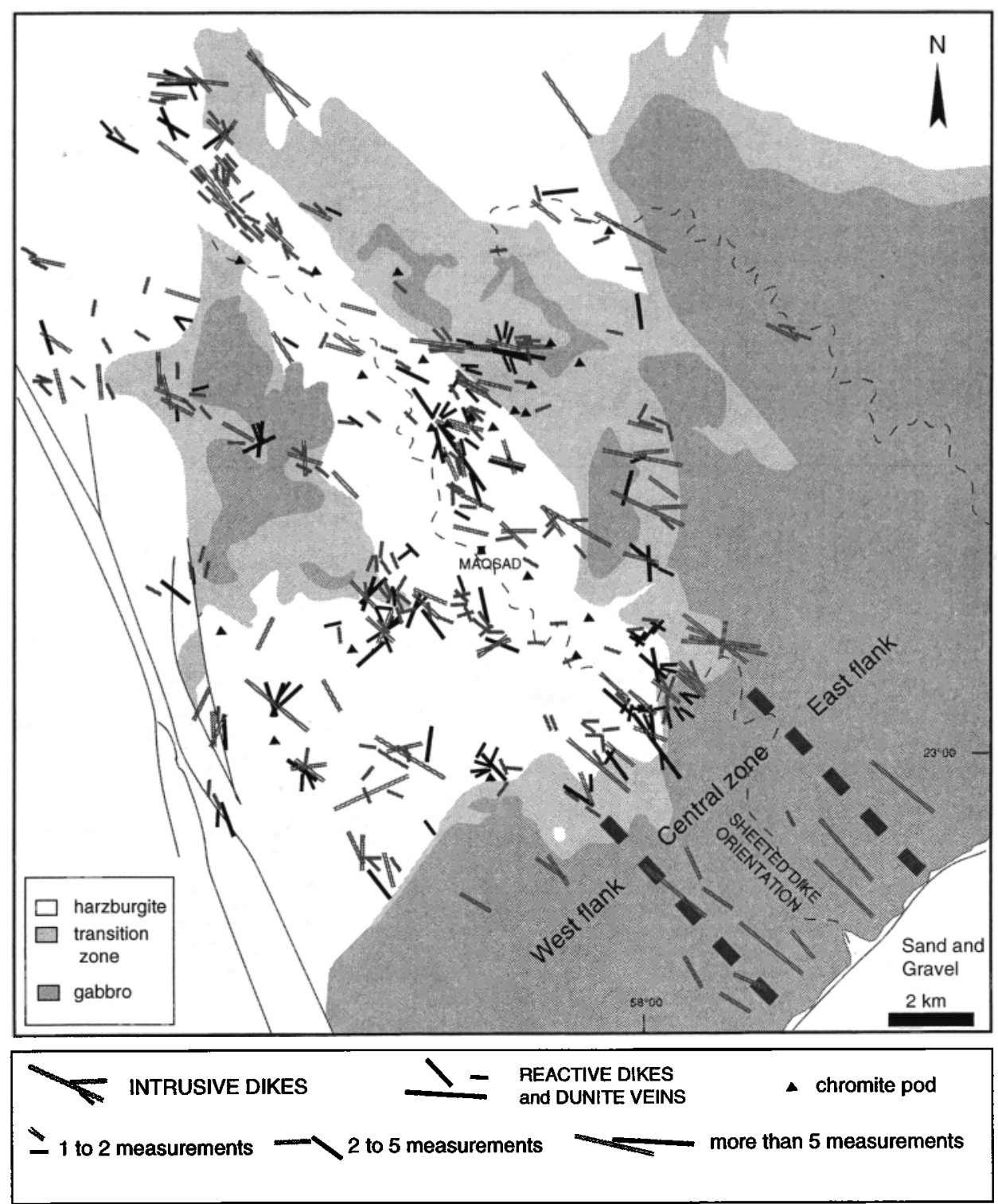

Figure 4. Map of dike intrusions.

the transition zone, from a few meters to $400 \mathrm{~m}$ below the Moho, illustrating again that the steep diapiric flow breaks through the horizontal transition zone limit and rotates to the horizontal very close to the Moho. These diapir heads do not produce a divergence of lineations nor do they modify the lineation trajectories issued from the " main feeding center." Between the three vertical areas, several horizontal measurements lie at low topographic elevations, indicating that, at least near the Moho, these three diapir heads are separated from one another.

Another interesting feature is the changing attitude of the Moho. It is dipping $15^{\circ}$ to the east near Tuff oasis, $30^{\circ}$ to the SE near Mahram, and $35^{\circ}$ to the south, SW of Mahram, following the shape of the diapiric flow as shown by Figure 5c. These different orientations, measured at elevations between 700 and $1300 \mathrm{~m}$, suggest a bulge of the Moho of at least $500 \mathrm{~m}$ above the main zone of steep lineations, where the transition zone is not exposed. In the absence of evidence for late deformation we interpret this bulge as a ridge feature.

\section{Cross Sections Through the Diapir}

Several cross sections (Figure 7) illustrate how sharply the steep lineations rotate to the horizontal, although the erosion that exposes the harzburgites at the center of the diapir has removed the transition zone and most sites of rotation above the vertical flow. Locations of the cross sections of Figure 7 are shown in Figure $8 \mathrm{a}$, where the thickness of the transition zone has been estimated thanks to complementary cross sections. All cross sections show that the rotation occurs in the upper $500 \mathrm{~m}$ below the Moho, in dunites and in some of the uppermost harzburgites. It may even occur in the upper $100 \mathrm{~m}$, as it is commonly observed that some of the steep lineations get very close to the Moho (Figures $5 b$ and $7 b$ ). In most cases, no curved hinges are observed, and the foliation planes are fan shaped, dipping outward from the diapir (Figures $7 \mathrm{a}$ and $7 \mathrm{c}$ ). This finding suggests a sharp corner flow, except in one location, where inward dipping foliations and lineations have been observed 


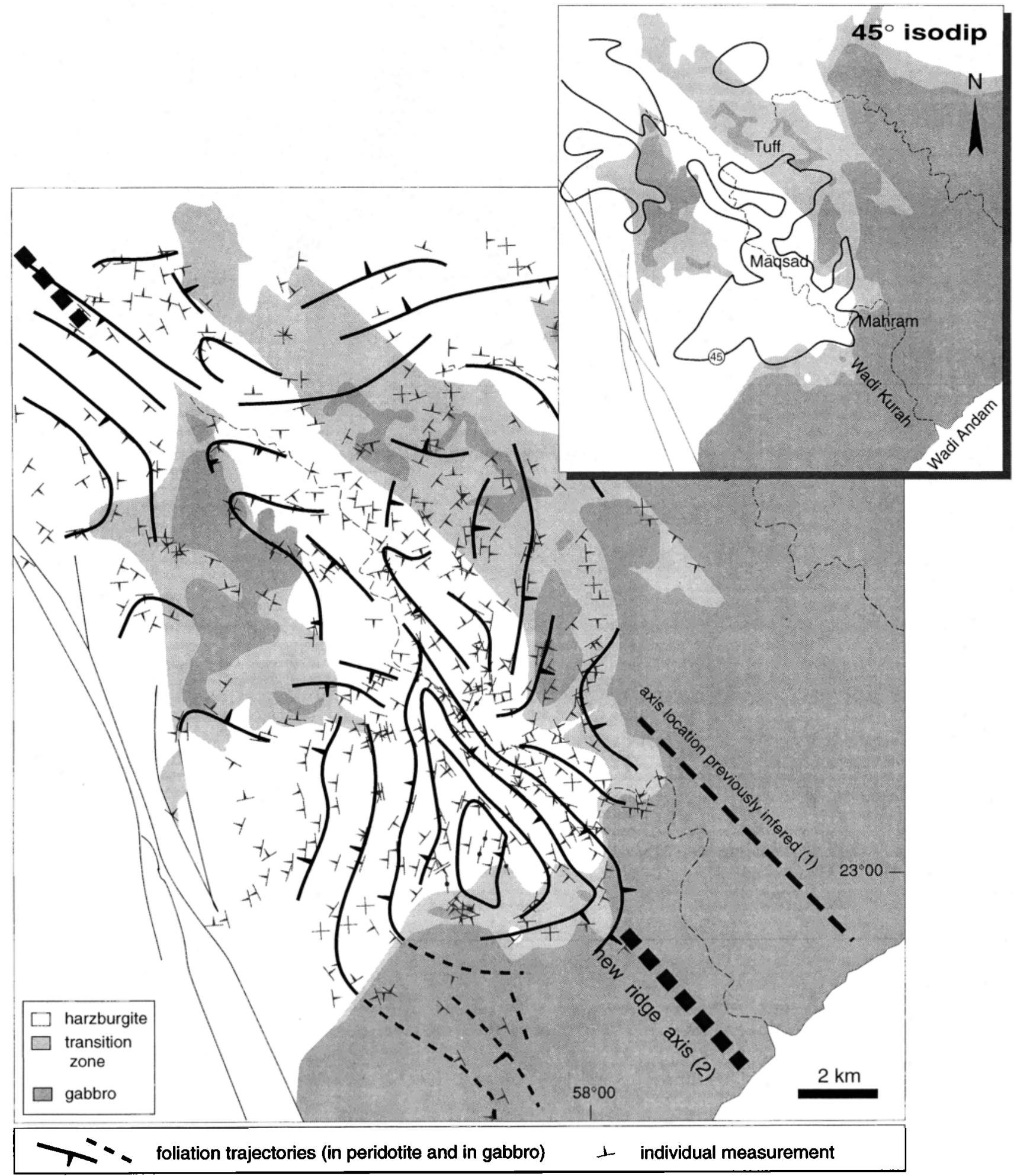

Figure 5a. Maps of planar structures including 509 individual measurements of foliation planes. Ridge axis locations correspond (1) to the location published by Ceuleneer [1991] and Nicolas and Boudier [1995], and (2) to that proposed in this study. 


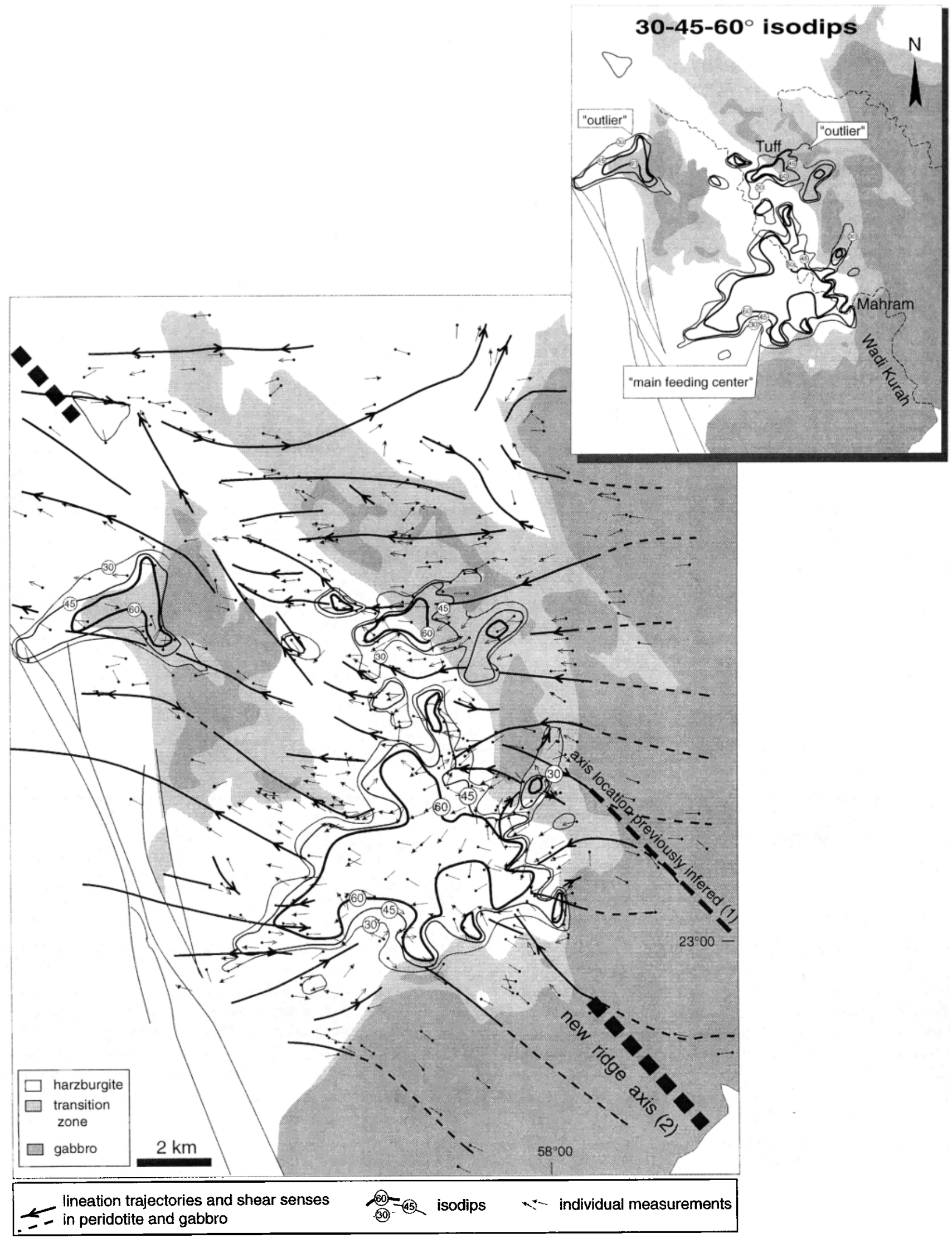

Figure 5b. Maps of linear structures including 460 individual measurements of lineations. Shear sense is indicated by arrows on trajectories and individual measurements. Plunge of lineations is indicated by dots at the tip of individual measurements. A "main feeding center" and two "outliers" are distinguished. 


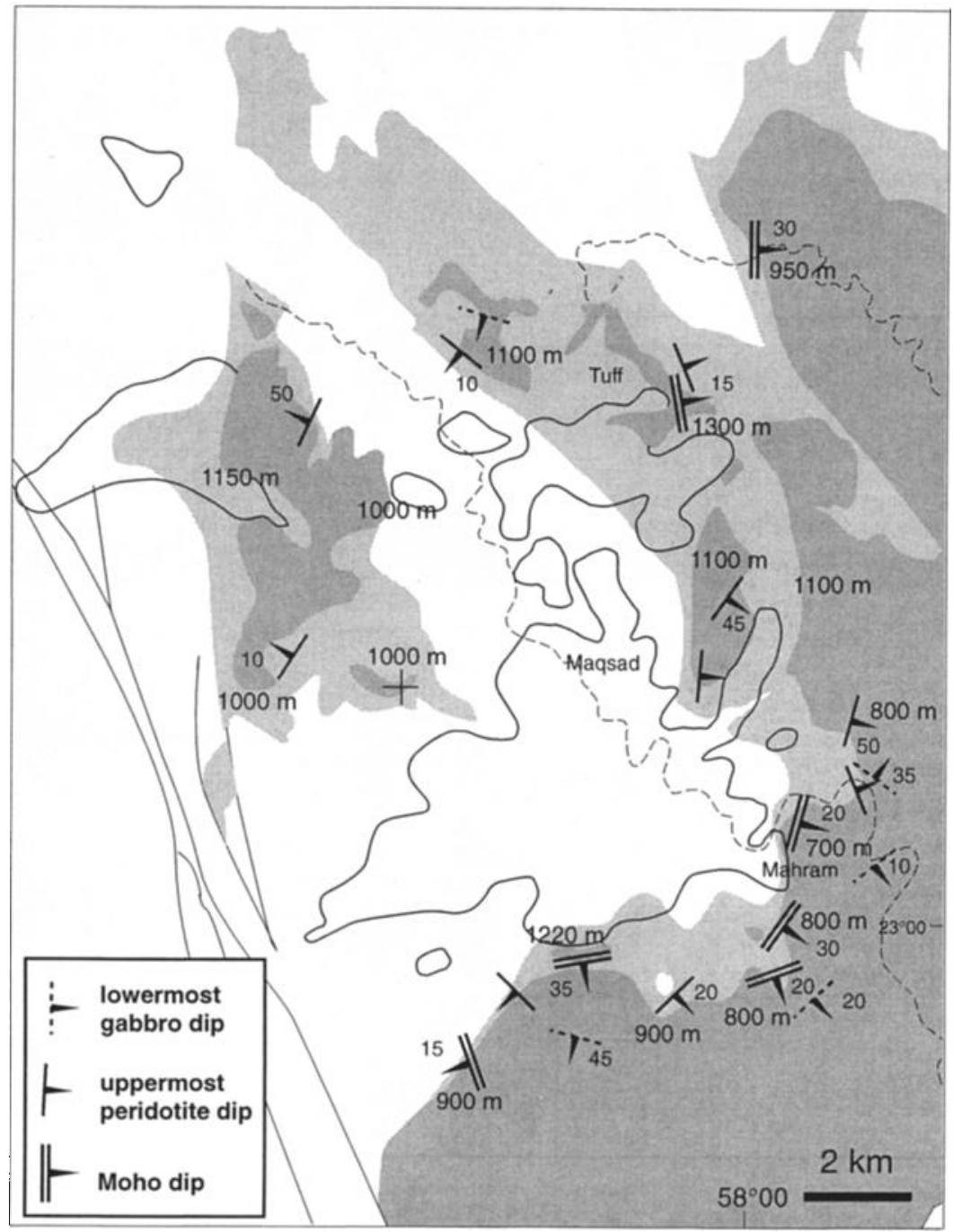

Figure 5c. Map of the Moho. Same legend as that in figure $5 \mathrm{a}$ and $5 \mathrm{~b}$. The contour of the $30^{\circ}$ lineation plunge is reported. Double bars correspond to Moho measurements, and single bars correspond to foliation measurements. Corresponding dips and Moho altitudes are indicated.

(Figure 7d). In the zone of rotation the crystallographic fabrics in peridotites vary from moderate to strong, except in a few areas, where traces of local intense melt circulation, such as chromite pods and plagioclase and/or clinopyroxene impregnations, are observed and no foliation is found; we call these "undeformed" or "untransposed" areas (Figures 7b and 7c). Foliations and gabbro lenses sometimes have nonconcordant orientations as in Figure 7e. The Moho is locally an irregular surface where the gabbro layering may not be parallel to the Moho (Figure 7d). From the different cross sections we have built a synoptic cross section that summarizes all observations (Figure 7f).

\section{Fabrics and Plastic Strain}

Although it is not known yet how to quantify the strain in peridotites, the strength of crystallographic fabrics allows a qualitative estimate, sufficient to map the distribution of strong and weak deformations. Twelve new crystallographic fabrics have been measured by using the universal stage and have been added to the four fabrics published by Boudier and Nicolas [1995]. They are representative of typical areas and structural situations. A fabric strength index $(J)$ was calculated for each sample (Figure 8) by using a method developed by Bunge [1982]. The index $J$ increases with axial strain and simple shear [Mainprice and Silver, 1993], ranging from 5 for the least deformed sample to 20 for the most deformed one (Figure 8a). In a second step these samples were used as a reference to estimate the fabric strength in other samples by a simple comparison of thin sections.

The strongest fabrics $(J>9)$ are found in the transition zone, associated with horizontal foliations, in contrast with weak fabrics $(5<J<7)$ which are mainly found in the diapiric area (Figure 8b). Four undeformed samples $(J<5)$ have been found in the untransposed areas, which never exceed $0.5 \mathrm{~km}^{2}$. Next to these areas the fabric strength is moderate to strong. The rarity and the limited size of undeformed areas suggest that they are not permanent stationary features beneath an active ridge. 

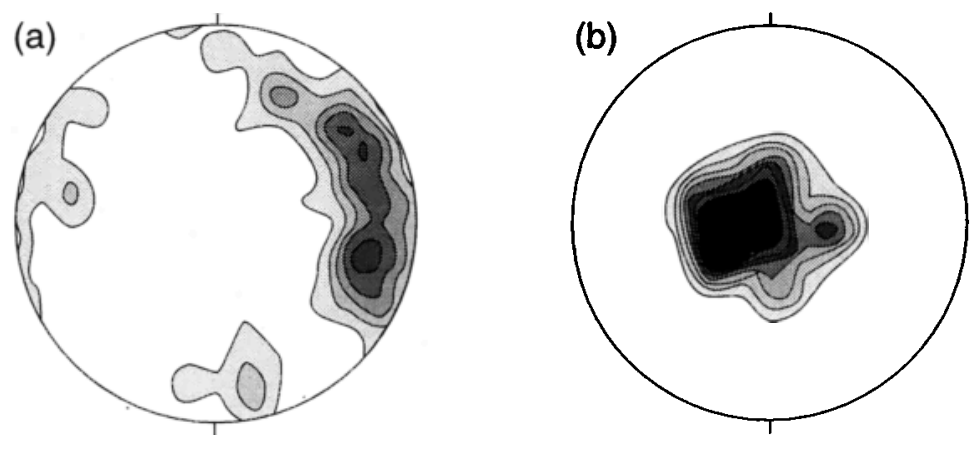

steep foliations 91 data

steep lineations 77 data
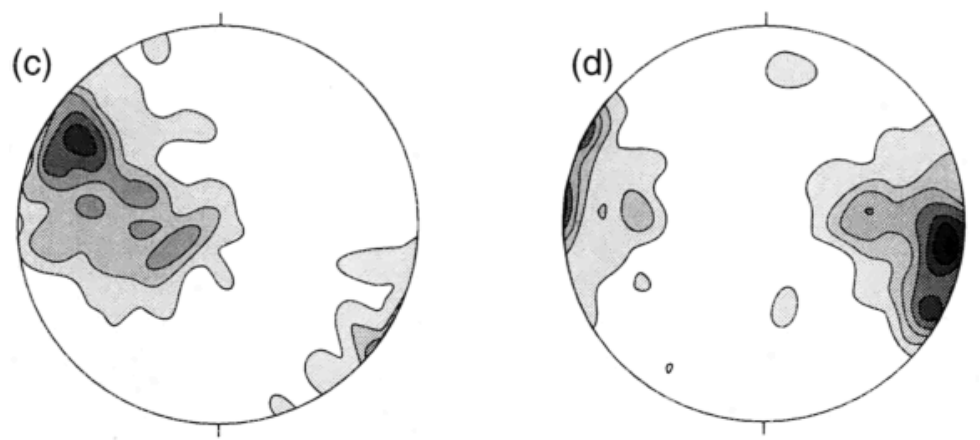

lineations, West flank 182 data lineations, East flank 140 data

Figure 6. Stereonets of penetrative structures. Lower hemisphere projection of poles to foliation planes and spinel lineations (contours at $1 \%, 2 \%, 4 \%, 8 \%$, and $16 \%$ ). (a) Foliations in the central zone of isodip $>45^{\circ}$ (Figure 5a); (b) lineations in the central zone of isodip $>45^{\circ}$ (figure $4 \mathrm{~b}$ ); and (c) and (d) lineations in the southwest and northeast domains, respectively, as defined in Figure 2.

\section{Discussion}

\subsection{Main Features of the Maqsad Diapir}

We summarize here and in Figure 9 our new observations dealing with the Maqsad diapir. The diapir is defined by three distinct areas of steep lineations. Altogether they define a broad zone covering about $100 \mathrm{~km}^{2}$. The main area is $7 \mathrm{~km}$ across the ridge axis and $6 \mathrm{~km}$ along this axis; the two others are smaller. The main area of steep foliations is also characterized by warped trajectories of the steep foliations. The Moho seems to follow the same shape and to bulge above the diapir and a thick Moho transition zone. Subhorizontal lineations tend to diverge from the main upwelling center with radial orientations becoming parallel and dominantly E-W, 6 to $8 \mathrm{~km}$ away from the diapir center. Lineations oriented parallel to the ridge trend (NW-SE) are found within a 1- to 3-km-wide band crossing the diapir. Lineations plunge outward from the main diapir, eastward on the eastern side, and westward on the western side. Apart from four small localized "undeformed" zones the fabric is always clearly pronounced. Steep lineations are correlated with areas of weak to moderate fabrics, whereas horizontal lineations are correlated with areas of moderate to strong fabrics. Finally, the pattern of mafic dikes in the mantle is also related to the main diapir as they strike at about $160^{\circ}$ on its western side and at $110^{\circ}$ on its eastern side.

\subsection{Relation of the Maqsad Diapir with a Paleoridge}

On the basis of a supposed concentric zoning of various dike types in the mantle section, centered on the diapir and suggesting emplacement at progressively greater distances from an active spreading center, it has been suggested that the Maqsad diapir was younger than parts of the surrounding crust and mantle [Ceuleneer, 1991; Ceuleneer et al., 1996]. Although we concur with this conclusion, our detailed mapping did not confirm such a distribution (Figure 4), and we interpret the occurrence of reactive veins, gabbro dikes, and diabases, definitely together in the same areas, as a consequence of the progressive in situ cooling of the paleoridge. The alignment of the Maqsad diapir with other diapirs along a NW-SE direction [Boudier et al., 1997] and the continuity of structures of uppermost peridotites and overlying gabbros strongly suggest that all beiong to a NW-SE ridge segment centered on these diapirs. Mapping at the scale of the ophiolite [Nicolas et Boudier, 1995; Boudier et al., 1997] shows that the NW-SE ridge opened in a slightly older oceanic lithosphere accreted along a NE-SW ridge. As the NE-SW ridge system is bounding the massif at about $25 \mathrm{~km}$ on each side of the Maqsad segment, we suggest that the NW-SE segment was active during 300,000 years tol Myr. (with spreading rates of 15-5 $\mathrm{cm} / \mathrm{yr}$. respectively). The ridge-centered diapirs contrast with the Mansah diapir (NE part of the Sumail massif), which displays vertical shear zones on its sides and large diabase intrusions in 
W CROSS SECTIONA
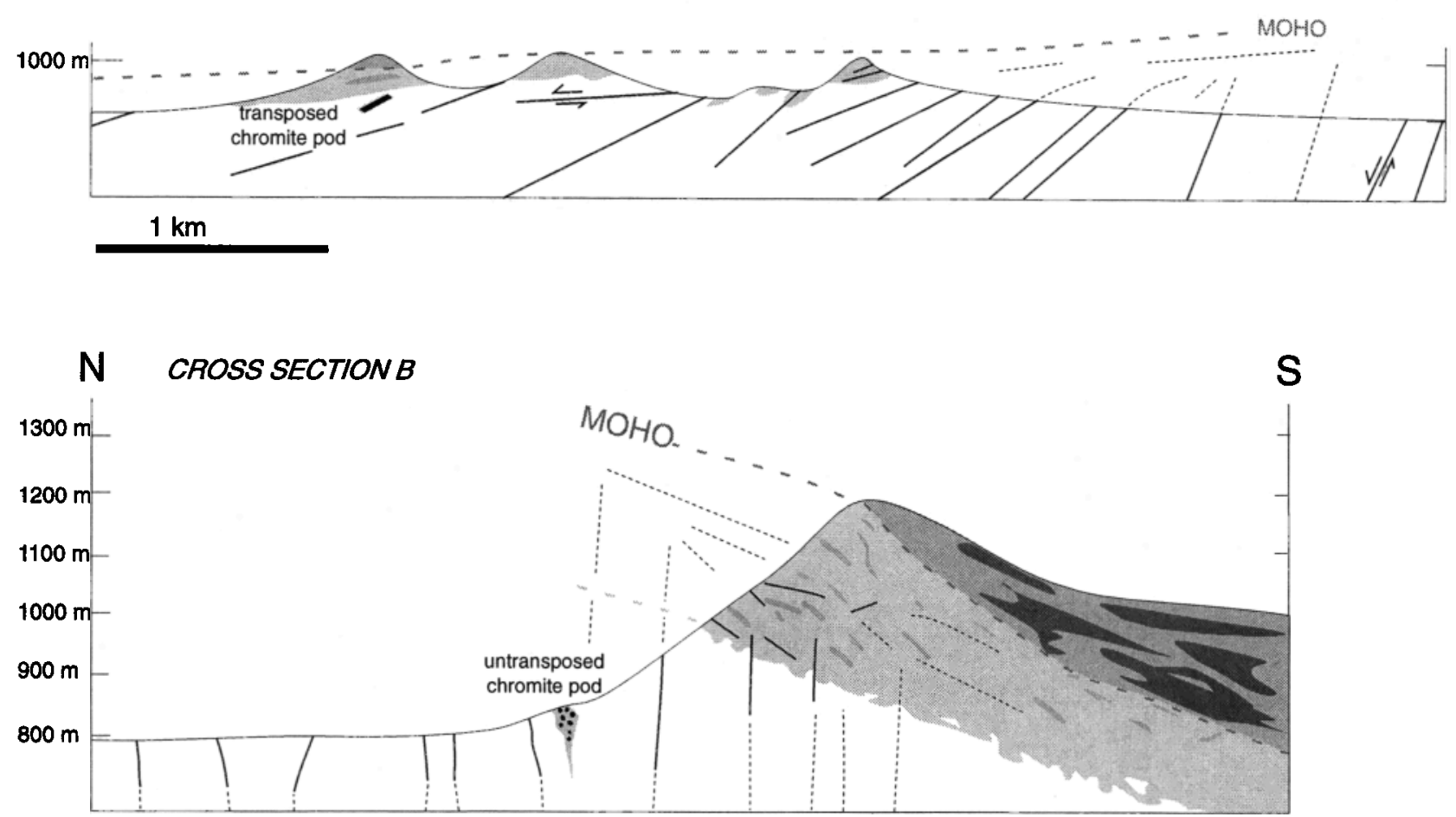

$1 \mathrm{~km}$

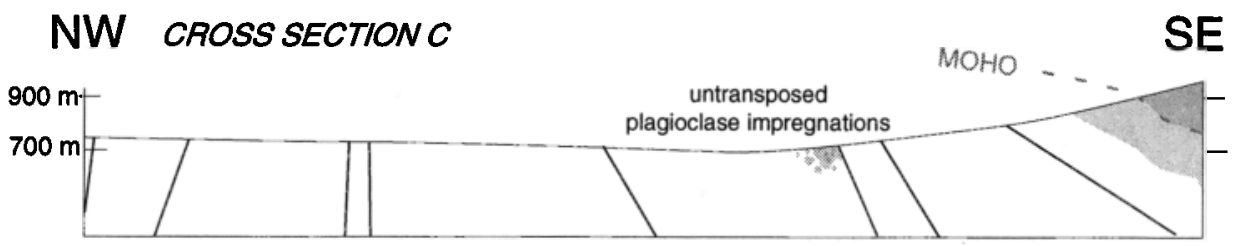

$1 \mathrm{~km}$

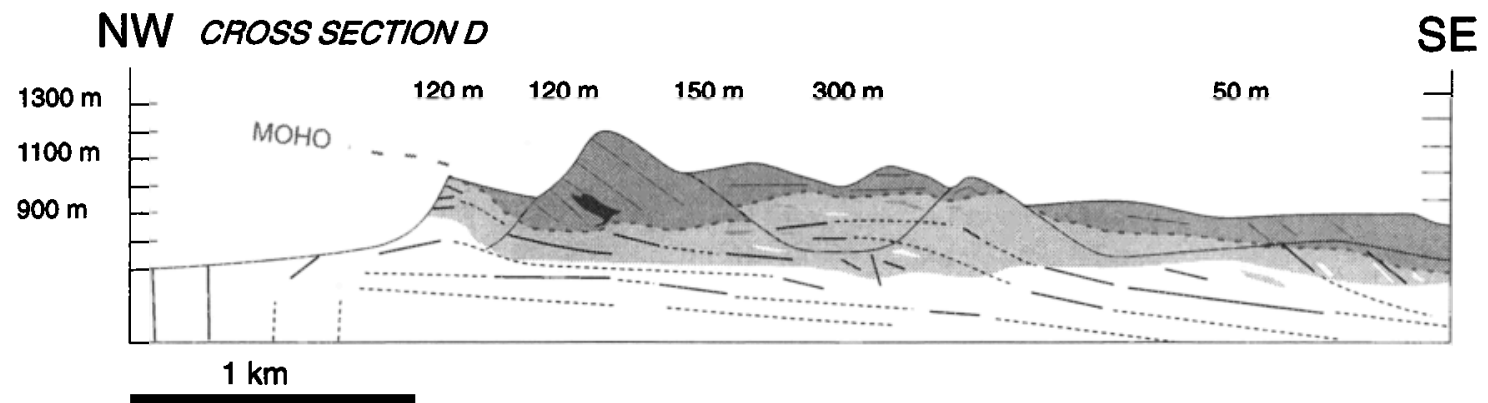

Figure 7. Cross sections (localization on figure 7a). White, harburgite; light gray, dunite; gray, gabbro; darker gray, wehrlite; black, chromite; solid lines, foliation planes; the cross sections are parallel to lineations' azimuth; and dashed lines, inferred structures. 


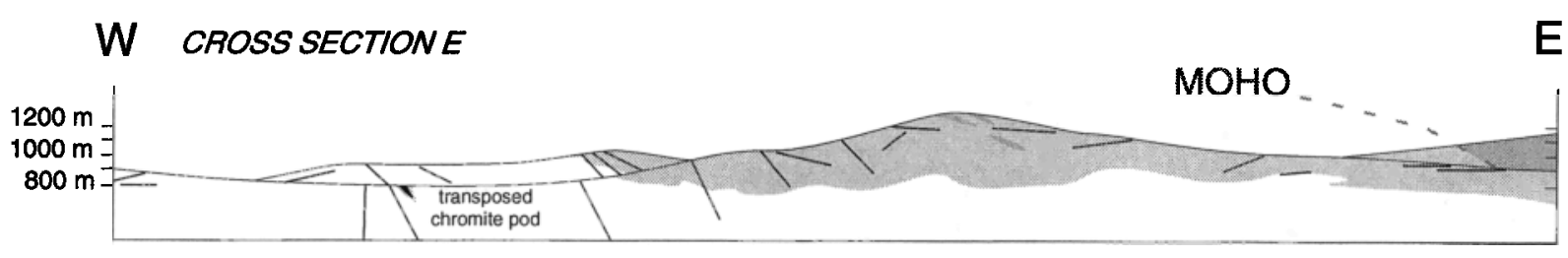

$1 \mathrm{~km}$

\section{SYNOPTIC CROSS SECTION}

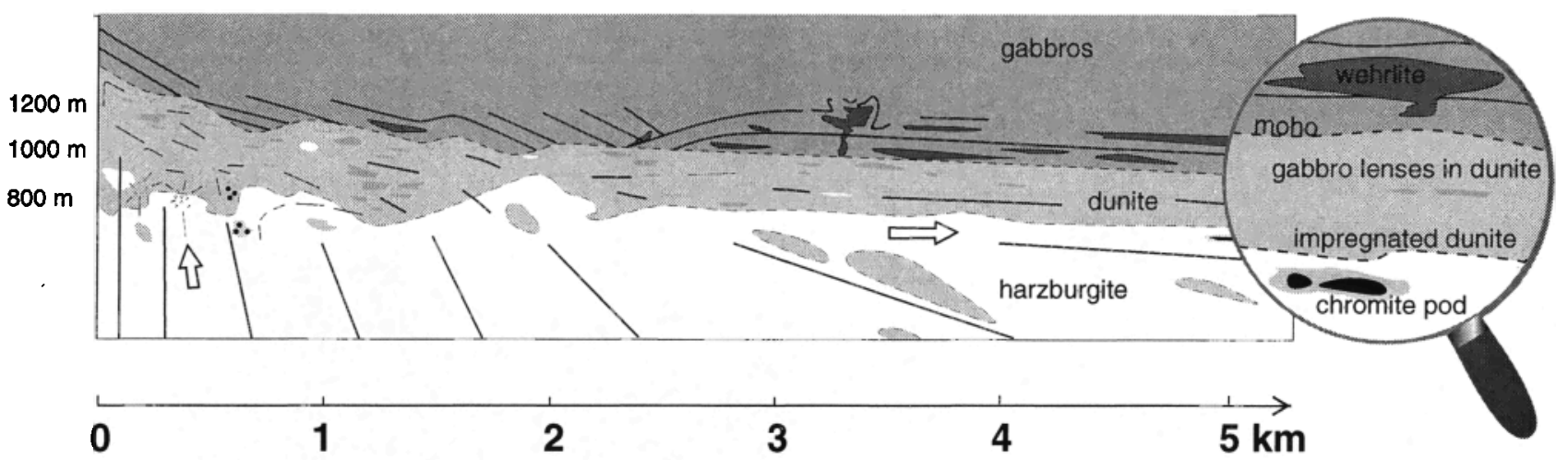

Figure 7. (continued)

the older and altered crust overlying the diapir, suggesting that it was intruding and injecting melt in a cooling lithosphere [D.Jousselin et al., manuscript in preparation, 1998], as predicted by its off-axis location [Boudier et al., 1997].

\subsection{Ridge Axis Location in the Maqsad Area}

The main criterion used so far to locate a paleoridge axis is that it should correspond to the limit between opposing shear senses in the mantle peridotite [Nicolas, 1989]. On this basis Ceuleneer [1991] and Ceuleneer and Rabinowicz [1992] located the ridge axis east of Wadi Kurah within the NW-SE elongated transition zone band (Figure 5), which also contains undeformed chromite pods, suggesting that it was an axial undeformed zone.

Other independent ways to locate the axis have been proposed by Nicolas and Boudier [1995]. The simplest suggestion is that it should be parallel to the sheeted dike complex and cross the diapir center; another is that it should coincide with the line of convergence of foliations in upper gabbros because this line should correspond to the roof of the magma chamber above the diapir [Chenevez et al., 1998; Nicolas et al., 1988b]. It could also be equated with the zone of intense diking, assuming that the ridge is fed through the diapir and has cooled in situ. These various criteria resulted in similar axis locations [Nicolas and Boudier, 1995].

As exemplified by studies of the Hilti massif [Ildefonse et al., 1995], it is commonly observed in the Oman ophiolite that horizontal peridotite lineations strike perpendicular to the sheeted dike complex orientation, and rarely parallel. Because of coupling between the active asthenospheric mantle flow and the flow induced by lithospheric drift, lineations issued from the diapir should be progressively rotated into parallelism with the spreading direction at distance from the diapir, thus restricting to the vicinity of the ridge axis the presence of lineations that are parallel to the ridge trend. The observation of a band of horizontal lineations parallel to the ridge trend running through the main diapir center leads us to locate the ridge axis $4 \mathrm{~km} \mathrm{SW}$ of the previous location proposed by Ceuleneer [1991] and Nicolas and Boudier [1995] (Figure 5). For these authors the diapir center, placed further east, was partly concealed below the transition zone, a possibility that two new observations tend to discard. First, steep lineations are commonly found, high into the transition zone, near the Moho, an observation that shows that the transition zone cannot entirely conceal the uprising flow pattern of a diapir. Second, the center of the main diapir head fits with the center of divergence of horizontal lineations. Another element revealed by the fabric map is that strong fabrics occur along the ridge axis location previously proposed, showing that it does not correspond to an axial undeformed zone.

Our new axis is no longer the limit between opposite shear senses on each side of the ridge. However, we note that regions that were previously unexplored have eastward shear senses on the west flank and westward shear senses on the east flank. 


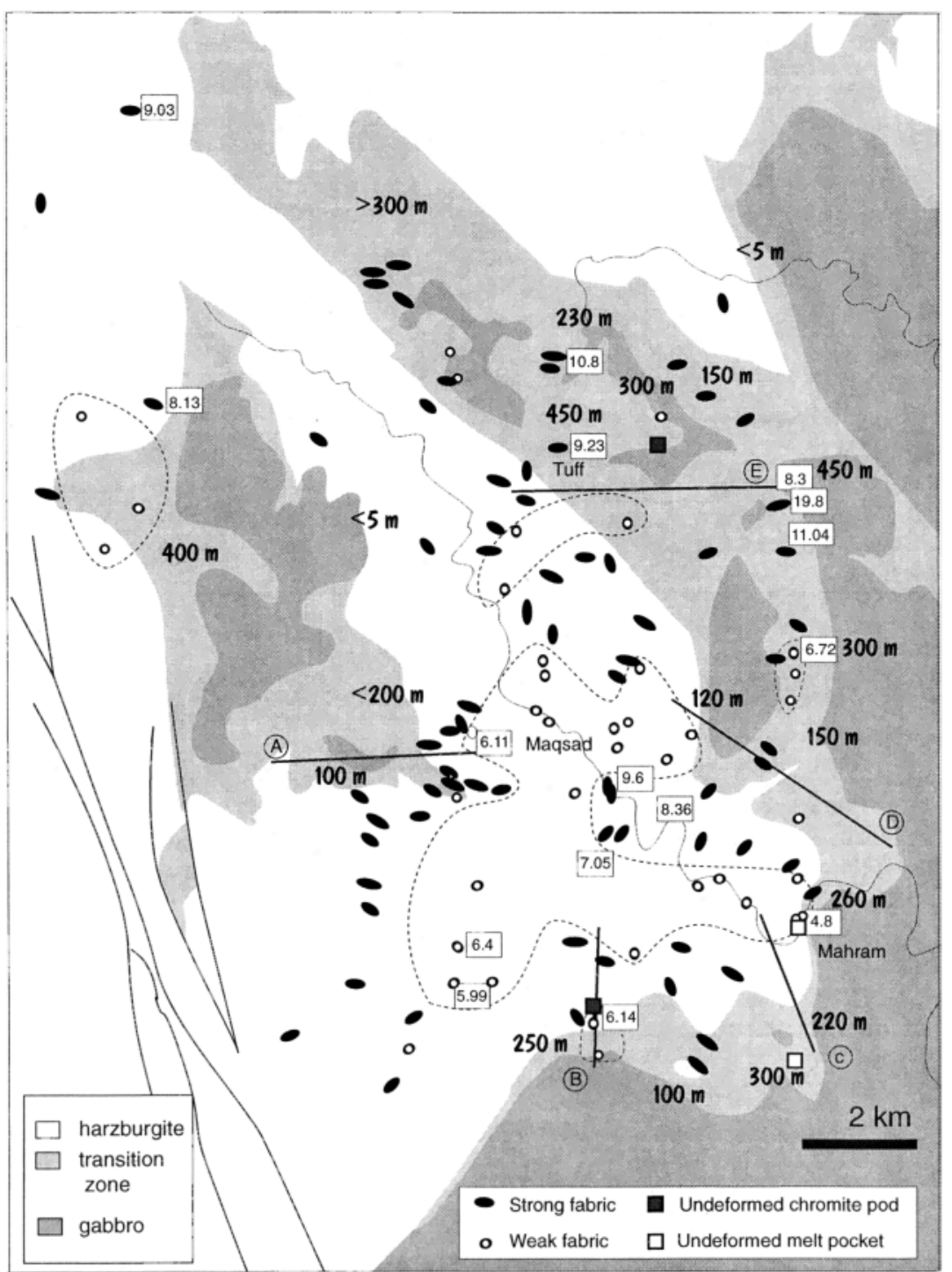

Figure 8a. Fabric map and cross sections situation. The calculated fabric strength of 16 samples is reported (boxes). Five classes of fabric strength were distinguished in comparison with these samples: lower than 5 corresponds to very weak, between 5 and 7 is weak, between 7 and 9 is moderate (not pictured), between 9 and 11 is strong, and higher than 11 is very strong. The main zones with weak fabrics are circled. The Moho transition zone thickness is also reported in bold letters.

95OD171 IMPREGNATED DUNITE, OLIVINE CRYSTALLOGRAPHIC FABRIC

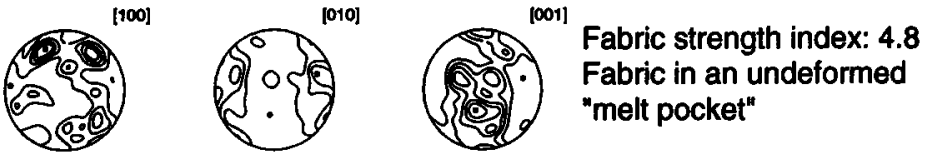

95OD121 IMPREGNATED DUNITE, OLIVINE CRYSTALLOGRAPHIC FABRIC

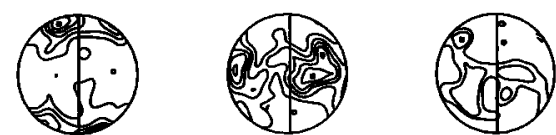

Fabric strength index : 6.14

Weak fabric

91OA133 IMPREGNATED DUNITE, OLIVINE CRYSTALLOGRAPHIC FABRIC
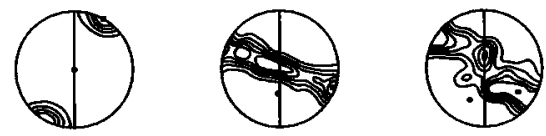

Fabric strength index : 19.8

Strong fabric

Figure 8b. Three examples of fabrics. Lower hemisphere equal area projections (contours at intervals of 1 times uniform, lowest contour X1). Structural reference system: foliation vertical, N-S, lineation vertical, N-S. 


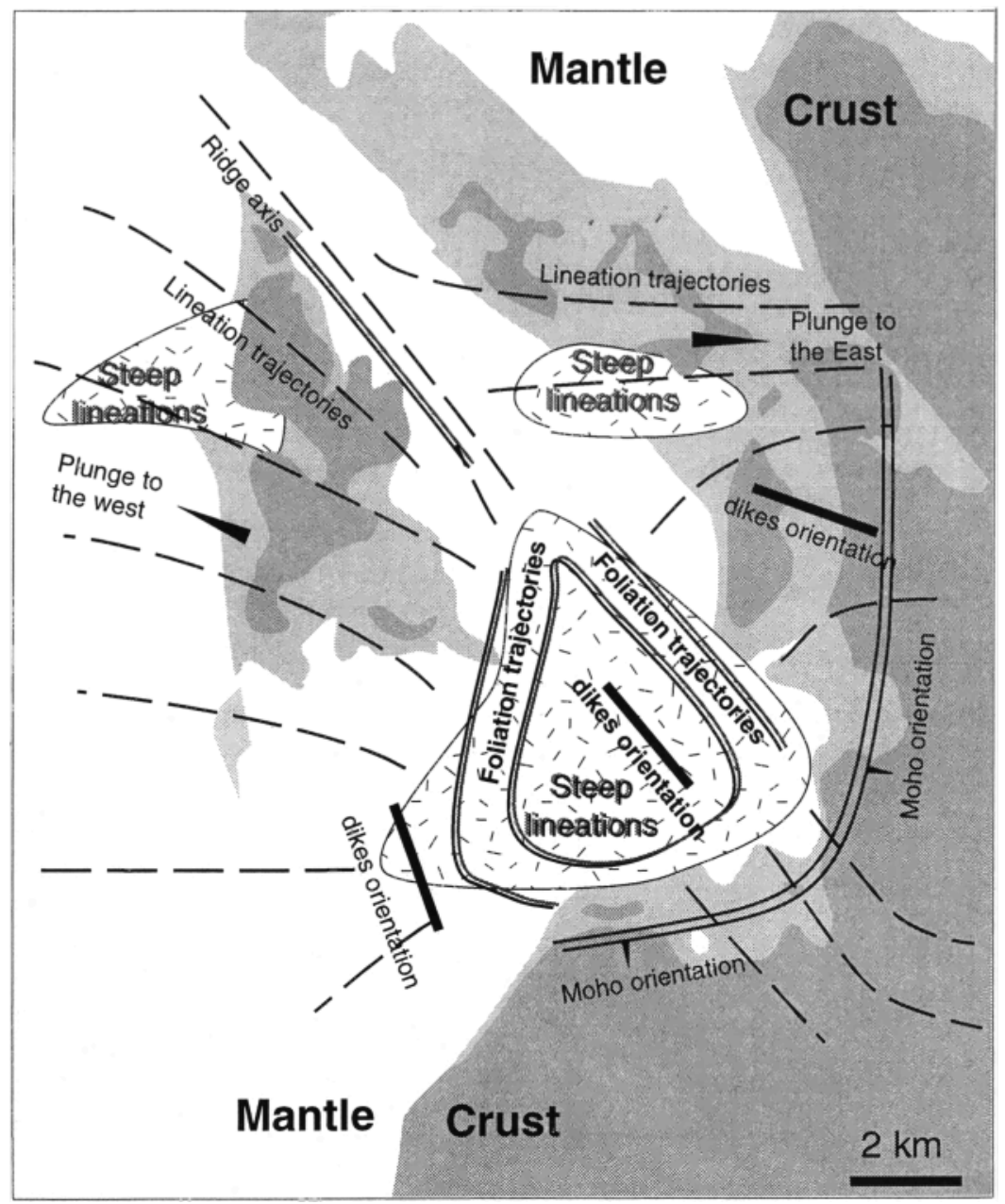

Figure 9. Sketch of the main features of the mantle Maqsad diapir. Same legend as that in Figure 4.

Therefore it becomes difficult to draw a sharp limit between areas with different shear directions. Other elements reinforce the new location of the ridge axis. This axis corresponds to the limit between lineations dominantly plunging to the west on the western side and to the east on the eastern side (Figure 6). The average mantle dike azimuths on each side of this axis are different too. Thus this new axis appears to be a major structural limit between two different zones.

\subsection{Two-Dimensional or Three-Dimensional structure}

In the 2-D mantle flow model the expected steep foliation trajectories should be oriented parallel to the ridge trend with no closure along strike [Ceuleneer, 1991; Ceuleneer and Rabinowicz, 1992], resulting in an orientation stereonet similar to the ones of the dikes. The warped trajectory of foliations (Figures $5 a$ and $6 a$ ) is more in agreement with a 3-D model. The warped Moho surface, the divergence of lineations, and the orientation of some lineations parallel to the ridge trend are additional evidences showing that the mantle flow at the paleoridge was 3-D. Another conclusion is that the mantle uprise was inhomogeneous in the diapiric area itself. Instead of one diapir with a vertical axial symmetry, three distinct heads are distinguished. Melt was inhomogeneously delivered, as illustrated by variations in the transition zone thickness. The thick transition zone has a limited extension along axis, probably reflecting the size of the melt source.

Finally, we noted previously that the dike pattern was different on each side of the paleoridge, thus departing from a 2-D symmetry. This pattern may reflect a 3-D stress field in the upper mantle during the last stages of the ridge accretion and the subsequent in situ cooling, in contrast with the remarkably uniform orientation of the overlying sheeted dike complex, which implies that the crustal lithospheric stress is more uniform than the underlying asthenospheric stress.

\subsection{Mantle Flow Pattern at Greater Depth}

The 3-D structure beneath the ridge governs the focusing of magmatic and tectonic activity and the interaction between the mantle and the crust forming above. It does not rule out the possibility that a more 2-D pattern or a larger diapir could exist at greater depth in the mantle, governing the ridge dynamics at a larger scale. At fast spreading centers, topography and seismic observations indicate that the crust attains its full thickness in no more than a few kilometers from the neovolcanic zone [e.g., Detrick et al., 1987]. If melt delivery was not strongly focused, we would expect the crust to thicken continuously far from a ridge. This important point is confirmed in many ophiolites and particularly in Oman by the observation that mafic dikes cutting 
through the layered gabbros are rather uncommon. If melt was still actively expelled away from the ridge, the gabbros, once crystallized on the sides of the magma chamber, should be cut by numerous dikes. Decompression melting becomes sufficiently important to form a melt connected network and make possible its extraction by porous flow and/or hydrofracturing at a depth of around $50 \mathrm{~km}$ [e.g., McKenzie, 1984; Nicolas, 1986]. Several authors [e.g., Rabinowicz et al., 1984; Scott and Stevenson, 1989; Sotin and Parmentier, 1989; Su and Buck, 1993] have suggested that focused melt delivery is driven by focused upwelling flow (either 2-D or 3-D). Other processes causing lateral movement of melt toward the ridge axis, resulting in focused melt delivery, have been suggested [e.g., Phipps Morgan et al., 1987; Sparks and Parmentier, 1991; Spiegelman and McKenzie, 1987]; though these processes may contribute to focusing melt into a narrow zone, we do not consider them in the following reasoning. In this end member scenario the 50 first $\mathbf{~ k m}$ of lithosphere have to be formed by mantle material that has been rising through a narrow conduit below the ridge. We assume that the Maqsad diapir corresponds to such a structure and consider that this diapir feeds the crust, and accretes $45 \mathrm{~km}$ of depleted mantle. A simple mass balance calculation of this situation provides some general constraints on the volume of the ascending flow and its velocity. Parameters used in these calculations are reported in Figure 10.
8.5.1. Velocity of the mantle flow in the diapir. The melt flux $\left(\phi_{m}\right)$ produced by the diapir can be approximately calculated by

$$
\phi_{\mathrm{m}}=f\left(S_{d} V_{d}\right)
$$

where $V_{d}$ is the upwelling flow velocity, $S_{d}$ is the diapir area in planform, and $f$ is the percentage of melt produced in the ascending diapir. On the other hand, a ridge segment, with a length $L$, a crustal thickness $e$, and a spreading rate $w$, has a "crustal flux" $\left(\phi_{c}\right)$ expressed as

$$
\phi_{\mathrm{c}}=L e w
$$

As the crust is only created from the melt produced by our diapir, we have $\phi_{\mathrm{m}}=\phi_{\mathrm{c}}$ and $V_{d}=($ Lew $) /\left(f S_{d}\right)$. Diapirs in Oman seem to be spaced at intervals of 20 to $30 \mathrm{~km}$ [Boudier et al., 1997]. Referring to marine situations, they may correspond to small segments of the order of 3 , limited by overlapping spreading centers, or to segments of the order of 4 , limited by devals [MacDonald et al., 1991]. Almost certainly, the three diapir heads in Maqsad are connected and derive from a large single diapir with a surface of about $100 \mathrm{~km}^{2}$. Crustal thickness is in the range of $4 \mathrm{~km}$ in Oman [Nicolas et al., 1996] to $6 \mathrm{~km}$ at the EPR [Detrick et al., 1987; Vera et al., 1990; Wang et al., 1996] and $f$ in the range of $10 \%$ to $20 \%$ [e.g., Klein and Langmuir, 1987; Niu

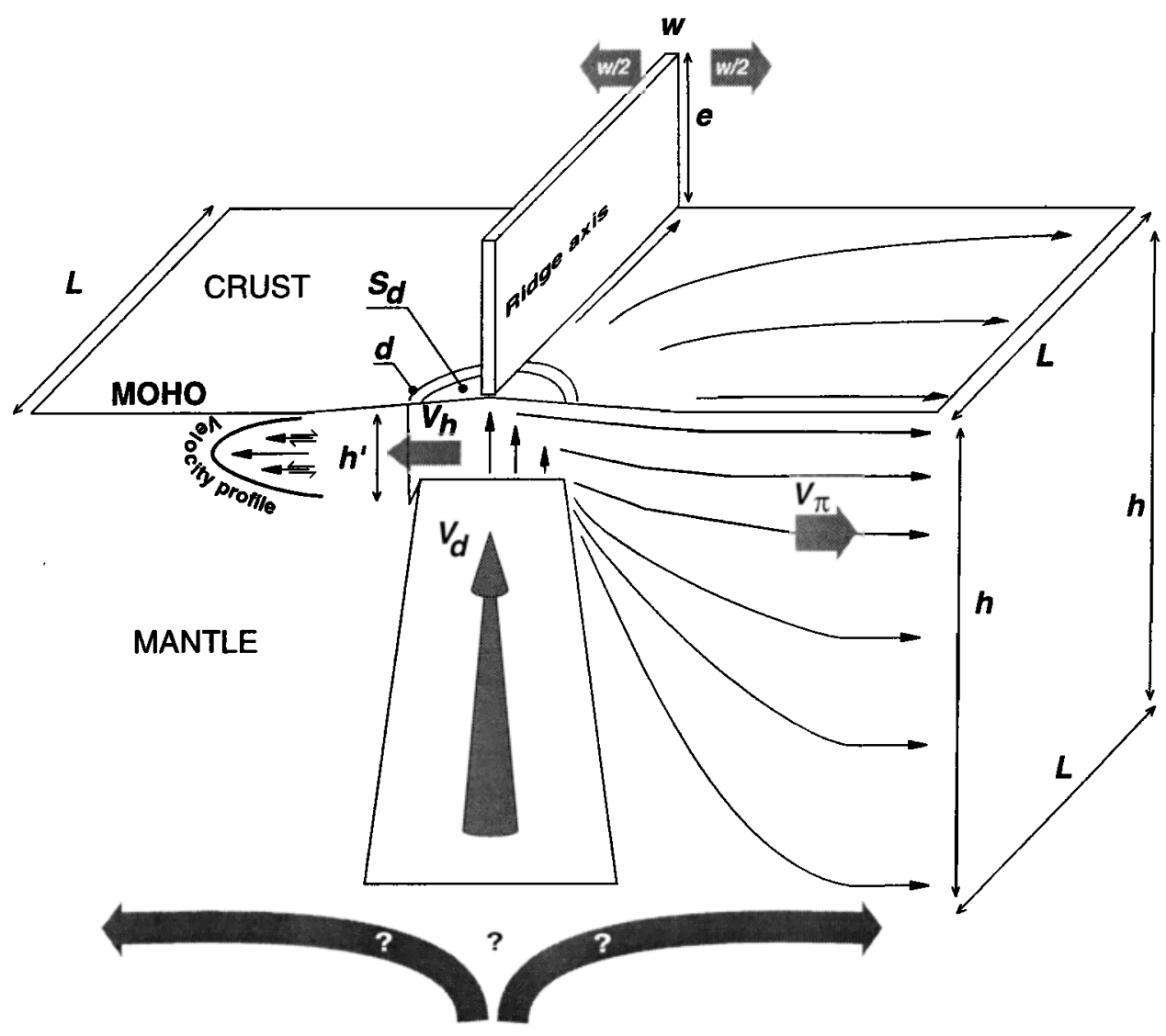

Figure 10. Schematic sketch of the mantle flux in relation to the overlying crust and the lithosphere. Symbols are as follows: $w$, spreading rate; $e$, crust thickness; $S_{d}$, surface occupied by the diapir; $d$, contour of the diverging flow layer; $V_{h}$, vertical flow velocity within the diapir; $V_{\pi}$, flow velocity, in the diverging flow; $h$, thickness of the lithosphere which can be formed by the diverging flow material; and $h$, thickness of the diverging flow layer. The velocity profile illustrated at the top of the mantle section (left side) is inferred from shear senses measured in the Maqsad and Hilti areas. 
and Hékinian, 1997; Presnall et al., 1979]. This gives a vertical flow velocity from 6 to 15 times the ridge spreading rate.

8.5.2. Thickness of the lithosphere that can be created by the diapir diverging flow. A similar mass balance can be made between the harzburgite flux produced by the diapir structure $\left(\phi_{\mathrm{d}}\right)$ and the flux of peridotite flowing away on each side of the ridge $\left(\phi_{\pi}\right)$. If we assume that, tens of kilometers away from the ridge, the average flow velocity of the peridotite expelled from the diapir is close to the ridge half spreading rate (a point discussed in the next paragraph), we have

$$
\begin{aligned}
& \phi_{\mathrm{d}}=S_{d} V_{d} \\
& \phi_{\pi}=L h w
\end{aligned}
$$

where $h$ is the thickness of the zone of outward flow and thus is the thickness of the lithosphere that can be formed by the peridotite coming from the diapir. This result gives $h=\left(S_{d} V_{d}\right) /(L w)$. Using the same values as those in section 8.5 .1 , we find that $h$ is 25 to $60 \mathrm{~km}$, which is in the range of the $45 \mathrm{~km}$ predicted by our initial assumptions.

These two estimations show that the Magsad diapir can account for the formation of a 25-km-long crustal segment if the upward flow extends over the entire region where steep structures can be found, and if the upward flow velocity is about $10 \pm 5$ times the ridge spreading rate. This velocity is inversely proportional to the surface of the upwelling zone. We note that this 3-D model compares well with the 2-D model proposed by $S u$ and Buck [1993].

\subsection{Horizontal Flow Velocities Near the Moho, at the Rim of the Diapir}

The geometry of the upwelling flow in maps and cross sections shows that the diverging flow expelled from the diapir is constrained along its rim to the upper $500 \mathrm{~m}$ of the mantle before it fans to fill the space between the thickening lithosphere and the horizon at 50-km depth, where it merges with the large-scale mantle flow (Figure 10). Therefore the velocity of the horizontal flow in the immediate vicinity of the diapir must be sufficiently high to keep the balance between the vertical and the diverging flows. A rough estimate of the average flow velocity in this zone is now presented. The diapir flux is given by equation (3). The horizontal flux from the diapir to the outside is given by

$$
\phi_{\mathrm{h}}=d h^{\prime} V_{h}
$$

where $d h^{\prime}$ is the surface of discharge ( $d$ is the perimeter of the diverging layer, and $h^{\prime}$ is its thickness) and $V_{h}$ is the average horizontal flow velocity. By equating (3) and (5) we deduce

$$
V_{h}=S_{d} V_{d} / d h^{\prime}
$$

$S_{d}, d$, and $h^{\prime}$ can be estimated: $S_{d}$ is in the range of $100 \mathrm{~km}^{2}$, $d=60 \mathrm{~km}$, and $h^{\prime}=500 \mathrm{~m} . V_{d}$ is taken in the range of 10 times a ridge spreading rate of $10 \mathrm{~cm} / \mathrm{yr}$. This calculation gives $V_{h}=270 \mathrm{~cm} / \mathrm{yr}$.

This may be an overestimation, as it does not take into account all the complexity of the diapir features, such as its three-headed structure at the top. However, this estimation shows that the horizontal velocity of the expelled material at the outskirt of the diapir is much higher than the ridge spreading rate. This high velocity must induce a forced flow and a high plastic strain in the transition zone and upper harzburgite; this explains the strong fabrics generally observed in the upper horizontal mantle flow, contrasting with the weaker fabrics in the diapir and the lower zone of diverging flow, with dips over $30^{\circ}$.
It has been suggested that shear direction inversions documented below the Moho in Oman and other ophiolites at depths not exceeding $2 \mathrm{~km}$ [Girardeau and Nicolas, 1981; Hoxha, 1993; Ildefonse et al., 1995; Prinzhofer et al., 1980] result from a forced flow, which is responsible for velocity profiles such that the maximum velocity corresponds to the point of shear direction inversion (Figure 10). This interpretation and previous field data from the Maqsad area [Ceuleneer, 1986; Ceuleneer et al., 1988] have inspired an active mantle diapirism model [Rabinowicz et al., 1984, 1987] which is bolstered by our new data. It explains why, near the Moho in the Maqsad area, the shear sense is a poor criterion to locate the ridge axis. Finally, another clear indication of forced flow is derived from the parallel orientation of the magmatic lineations in the basal layered gabbros with the plastically developed lineations in the upper mantle rocks [Chenevez et al., 1998; Ildefonse et al., 1995; Nicolas, 1989; Nicolas and Boudier, 1995; Pallister and Hopson, 1981; this study]. This observation has been attributed to mechanical coupling with the underlying flowing mantle dragging the overlying magmatic gabbros.

The horizontal flow velocity rapidly decreases with the distance from the diapir, as the surface of discharge increases. $V_{h}$ decreases to $5 \mathrm{~cm} / \mathrm{yr}$ (i.e., the half spreading rate) at $10 \mathrm{~km}$ away from the diapir, where $d$ is roughly $120 \mathrm{~km}$, and the diverging layer thickness $\left(h^{\prime}\right)$ is around $12 \mathrm{~km}$ if the flow follows a slope of $50^{\circ}$ along its lower limit. This finding means that at this distance from the ridge axis the mantle flow becomes passive and coupled to the lithospheric plate motion. Thus $10 \mathrm{~km}$ from the diapir, lineations should turn into parallelism with the spreading direction. The overall E-W trend of lineations (Figure 6) 6 to $8 \mathrm{~km}$ from the diapir core suggests that the spreading direction at the Maqsad ridge was oblique to the NW-SE axis direction.

\subsection{The Flow Rotation on Top of the Diapir}

The sharp rotation of the lineations at the top of the Maqsad diapir has been previously described by Ceuleneer et al. [1988], Ceuleneer and Rabinowicz [1992], and Boudier and Nicolas [1995]. These studies favor a simple model that consists of a vertical flow up to about $500 \mathrm{~m}$ below the Moho, with a sharp bend to horizontal flow in the transition zone. The sharp rotation is made possible by a drop of 4 orders of magnitude in viscosity within the last $2 \mathrm{~km}$ below the Moho [Rabinowicz et al., 1987]. The viscosity drop is due to the intense melt circulation, which destroys the peridotite solid framework and incidentally turns the harzburgite into a dunite. In this interpretation the peridotite loses its fabric at the top of the diapir before being channeled in a fast moving horizontal flow, where it acquires a new fabric by compaction and shear flow.

Our study confirms many elements of this model. We observe a sudden $90^{\circ}$ rotation of the ascending flow at the top of the diapir, inducing a forced horizontal flow. However, there is no compelling evidence that the peridotites lost their fabrics at any time: the fabric is always clearly pronounced, except in the four local areas described above, where the fabric is very weak $(J<5)$. We offer two explanations for the sharp rotation that still assume a decrease of viscosity but without destruction of the plastic flowinduced fabrics. The first explanation is that the peridotite solid framework at the top of the diapir was only dismembered along a magma network, separating solid lenses. The lenses, generated at any scale, could freely slip one on the other, but the fabrics would be preserved and still visible at the sample scale. This interpretation could explain the nonconcordant and discontinuous 
structures in Figure 7e and account for the presence of some harzburgites within the zone of rotation; as melt would concentrate around the lenses, they would have escaped being transformed into dunites. When magmatic plagioclase and clinopyroxene are present (5\% to $20 \%$ ), they are always distributed in elongated beads parallel to the foliation and the lineation, without any destruction of the solid framework. Such textures are observed in the horizontal transition zone [Boudier and Nicolas, 1995; Jousselin et ah, 1996] and also occasionally in the uppermost steeply dipping depleted harzburgites. This observation leads to our second suggestion: the viscosity of the dunite may be reduced a few orders of magnitude with the introduction of a melt component distributed parallel to the penetrative structures, thus with no destruction of the solid framework. Hirth and Kohlstedt [1995] show that at a melt fraction of $7 \%$ the strain rate is enhanced by a factor of 25 relative to melt free (viscosity decrease of 1.4 orders of magnitude). In the crytallizing and flowing gabbros of the crustal section above the diapir, Nicolas and Ildefonse [1996] suggest a drop of viscosity of 3 orders of magnitude with respect to solid gabbros, within a suspension flow with a low melt fraction and strong fabrics. They conclude that melt may promote this viscosity drop by a dissolution process. Similar processes may occur within the underlying transition zone, where the viscosity should also be comparable in order to account for the mechanical coupling between the two units evoked above. These propositions are open for further investigations.

As Ceuleneer and Rabinowicz [1992] pointed out, another interesting feature of the diapir lies in its open downward fan shape, which we found in several cross sections (Figures 7a, and 7c). Ceuleneer and Rabinowicz [1992] interpret this form as the result of focusing of the upward flow toward the ridge axis, due to the viscosity decrease. We agree with this conclusion but not with their schematic cross sections showing curved dunite bodies in the hinge between vertical and horizontal flow, the inward dipping foliations, and the progressive thinning of the transition zone away from the diapir.

\section{Comparison With Marine Geophysical Data}

Recent interpretations of gravity and topography at the EPR suggest the presence of a 10-km-wide across the ridge, 30- to 70 km-deep region of buoyant mantle [Magde et al., 1995; Wang and Cochran, 1993; Wilson, 1992] containing a few percent melt. Focused upwelling and melting have been inferred. The weak variation of gravity and topography along axis is interpreted either as 2-D mantle structure or as 3-D mantle structure with very efficient along-axis transport of crustal material [Cormier et al., 1995]. Wang et al. [1996] and Barth and Mutter [1996] point out the difficulty in interpreting these data in the absence of seismic constraints on the crustal thickness. They propose that the combination of thin crust, bathymetric high, and mantle gravity low is the signature of a diapiric upwelling beneath the EPR, near $9^{\circ} 40^{\prime}$ to $9^{\circ} 50^{\prime}$. Although more constraints would be necessary, especially along axis, the dimensions of upwelling inferred from these studies fit well with those of the diapiric area we found. We recall that a compilation of crustal thickness in Oman has resulted in the conclusion that crust was about $2 \mathrm{~km}$ thinner above diapirs [Nicolas et al., 1996], a common point with Wang et al. [1996] and Barth and Mutter [1996].

Other constraints can be derived from the results of seismic tomography experiments, which reveal variations in velocity and azimuthal anisotropy. Three-dimensional images show an axially segmented low-velocity volume in the crust at depths of $1-3 \mathrm{~km}$ [Toomey et al., 1990] and in the mantle within $4 \mathrm{~km}$ of the Moho [Dunn and Toomey, 1997]. These results imply that the rise axis is thermally segmented on the 10-km scale and suggest that this scale of segmentation is imposed by the dynamics of melt generation and transport [Solomon and Toomey, 1992; Toomey et al., 1990]. This phenomenon alone does not prove the presence of diapirs with shapes similar to Oman, but it is in favor of a 3-D mechanism for focused melt transport to the ridge. At first sight the seismic anisotropy, showing a regular pattern of fast mantle velocities parallel to the spreading direction, is more consistent with 2-D mantle flow diverging from the rise [Dunn and Toomey, 1997] than with a 3-D model in which some radial flow is expected. Near the main diapir head of Maqsad, apart from the 3$\mathrm{km}$-wide corridor of lineations parallel to the rise axis, the lineations rotate in a homogenous direction (Figure 6) assumed to be the spreading direction at a relatively short distance ( 6 to 8 $\mathrm{km}$ ) from the diapir. Thus the anisotropy recorded at the EPR may not contradict a 3-D upwelling flow model.

\section{Conclusion}

The paleospreading center of Maqsad was fed by a 3-D mantle diapir with a weak vertical axial symmetry. As summarized in Figure 8, our detailed structural study has resulted in a much sharper image of this fundamental feature of an oceanic ridge. The main diapir head, where the lineations diverge, has a diameter of $6 \mathrm{~km}$ and is accompanied by smaller heads, together covering a diapiric region of about $100 \mathrm{~km}^{2}$. The zone of divergence of lineations from the main diapir is $12 \mathrm{~km}$ wide, with a 1- to 3-km-wide corridor of lineations parallel to the ridge axis and a well-pronounced preferred direction on each flank, possibly corresponding to the paleospreading directions. Trends and dips of the uppermost mantle structures and of the Moho define an upward bulge in the Moho of a few hundred meters, reflecting the shape of the diapir.

Melt at the top of the diapir may have been delivered all along the Moho transition zone, which extends about $8 \mathrm{~km}$ past the diapir limits. We propose that the association of thick transition zones and diapirs is due to melt being delivered by focused mantle upwelling, at least in the uppermost mantle. The dunite of the transition zone might have contained as much as $10 \%$ melt that may have decreased the rock viscosity, so that the transition zone constituted not only a compositional but also a rheological transition between peridotites and gabbros. This viscosity drop could have allowed the sharp rotation of flow from vertical to horizontal, as is recorded close to the Moho. Mass balance estimates point to a vertical flow velocity within the diapir 5 to 15 times larger than the spreading rate, thus allowing focusing below the ridge and providing enough melt to feed the crust. This, in turn, induced a forced horizontal flow, also with a high velocity, to which are ascribed the strong fabrics in the horizontal structures. The coupling of gabbro structures with mantle structures is also ascribed to this active flow. The flow velocity decreased outward, until at a distance of 6 to $8 \mathrm{~km}$ from the diapir it had fallen to the spreading velocity. Beyond that, no more lineation divergence is observed, and passive flow should have dominated.

Acknowledgments. This work is based on numerous field data acquired together with successive members of our group: G. Ceuleneer, K. Benn, V. Thomas, I. Reuber, E. Gnos, and B. Ildefonse, who also helped through discussions. We thank B. Hacker, P. Kelemen, and R.T. Gregory for very thorough and profitable reviews. Technical assistance 
for the thin sections has been provided by $\mathrm{C}$. Nevado. This study was possible thanks to the hospitality of $\mathrm{M}$ Kassim and $\mathrm{H}$. Al Azri from the Minıstry of Mines and Petroleum of Oman and financial support from CNRS-INSU and a governmental doctoral fellowship.

\section{References}

Auzende, J.M., D. Bideau, E Bonatti, M. Cannat, J. Honnorez, J. Malavieille, V. Mamaloukas-Frangoulis, and C. Mevel, Direct observation of a section through slow-spreading oceanic crust, Nature, 337, 726-729, 1989.

Barnoin-Jha, K., E.M. Parmentier, and D.W. Sparks, Buoyant mantle upwelling and crustal production at oceanic spreading centers: Onaxis segmentation and off-axis melung, J. Geophys. Res., 102, 11,979. $11,989,1997$.

Barth, G.A., and J.C. Mutter, Variabılity in oceanic crustal thickness and structure: Multichannel seismic reflection results from the northern East Pacific Rise, J. Geophys. Res., 10I, 17,951-17,975, 1996

Beurrier, M., Géologie de la nappe ophiolitique de Semail dans les parties onentale et centrale de l'Oman, Ph.D. thesis, Univ. Paris VI, 1987.

Boudier, F., and A. Nicolas, Harzburgite and lherzolite subtypes in ophiolitic and oceanic environments, Earth Planet Sci. Lett., 76, 84$92,1985$.

Boudier, F., and A. Nicolas, Nature of the Moho transition zone in the Oman ophiolite, J. Petrol., 36, 777-796, 1995.

Boudier, F., G. Ceuleneer, and A. Nicolas, Shear zones, thrusts and related magmatism in the Oman ophiolite: Initiation of thrusting on an oceanic ridge, Tectonophysics, 151, 275-296, 1988.

Boudier, F , A Nicolas, B. Ildefonse, and D. Jousselin, EPR microplates: A model for the Oman ophiolite, Terra Nova, 9, 79-82, 1997.

Buck, W R., and W Su, Focused mantle upwelling below mid-ocean ridges due to feedback between viscosity and melting, Geophys. Res. Lett., 16, 641-644, 1989.

Bunge, H.J., Texture Analysis in Materials Science., 593 pp., Butterworths, London, 1982

Cassard, D., A. Nivolas, M. Rabinowicz, M. Moutte, M. Leblanc, and A. Prinzhofer, Structural classification of chromite pods in southern New Caledonia, Econ. Geol., 76, 805-831, 1981.

Ceuleneer, G, Structure des ophiolites d' Oman: Flux mantellaire sous un centre d'expansion océanique et charrage à la dorsale, thèse de doctorat, Univ. de Nantes, 1986.

Ceuleneer, G., Evidence for a paleo-spreading center in the Oman opholite: Mantle structures in the Maqsad area, in Ophiolite Genesis and Evolution of the Oceanic lithosphere, edited by T. Peters, A. Nicolas, and R G. Coleman, pp. 147-173, Kluwer Acad. Norwell, Mass., 1991

Ceuleneer, G., and M. Rabinowicz, Mantle flow and melt migration beneath oceanic ridges : models derived from observations in ophiolites, AGU Geophys. Monogr. 71, pp. 123-154, 1992.

Ceuleneer, G., A. Nicolas, and F. Boudier, Mantle flow patterns at an oceanic spreading centre: the Oman peridotites record, Tectonophysics, 151, 1-26, 1988.

Ceuleneer, G., M. Monnereau, and I. Amri, Thermal structure of a fossil diapir inferred from the distribution of mafic cumulates, Nature, 379 . 149-153, 1996.

Chenevez, J., P. Machetel, and A. Nicolas, Numerical models of magma chambers in the Oman ophiolite, J. Geophys. Res., in press, 1998.

Cormier, M.H., K.C. Macdonald, and D.S. Wilson, A three-dimensional gravity analysis of the East Pacific Rise from $18^{\circ}$ to $21^{\circ} 30^{\prime} \mathrm{S}, \mathrm{J}$. of Geophys. Res., 100, 8063-8082, 1995.

Crane, K., The spacing of rift axis highs: Dependence upon diapiric processes in the underlying asthenosphere?, Earth Planet. Sci Lett., $72,405-414,1985$.

Detrick, R.S., P. Buhl, E. Vera, J. Mutter, J. Orcutt, J. Madsen, and T. Brocher, Multi-channel seismic imaging of a crustal magma chamber along the East Pacific Rise, Nature, 326, 35-41, 1987.

Dunn, R.A., and D.R. Toomey, Seismological evidence for threedimensional melt migration beneath the East-Pacific Rise, Nature, 388, 259-262, 1997.

Girardeau, J., and A. Nicolas, Structures in two of the Bay of Islands (Newfoundland) ophiolite massifs: a model for oceanic crust and uppermantle, Tectonophysics, 77, 1-34, 1981.

Hacker, B.R., Rapid emplacement of young oceanic lithosphere: Argon geochronology of the oman ophiolite, Science, 265, 1563-1565, 1994.

Hirth, G, and D.L. Kohlstedt, Experimental constraints on the dynamics of the partially molten upper mantle Deformation in the diffusion creep regime, J. of Geophys. Res., 100, 1981-2001, 1995.
Hoxha, M., Etude structurale et pétrologıque de l'ophılite de Kukes (Albanie): Cinématique de la déformation et géométrie de la ride, thèse, Univ. de Nancy, 1993.

Ildefonse, B., S. Billiau, and A. Nicolas, A detalled study of mantle flow away from diapirs in the Oman opholıte, in Mantle and Lower Crust Exposed in Oceanic Ridges and in Opholltes, edited by R.L M Vissers and A. Nicolas, pp. 163-177, Kluwer, Norwell, Mass., 1995.

Jousselin, D., D. Mainprice, and F. Boudier, Structure, seismic velocities, and anisotropy of the mantle at fast-spreading ridges, Eos Trans. $A G U, 77$ (46), Fall Meet. Suppl., F665, 1996.

Kelemen, P.B., Reaction between ultramafic rock and fractıonatıng magma, 1, Phase relations, the origin of calc-alkaline magma sernes, and the formation of discordant dunite, J. Petrol., 31, 51-98, 1990.

Klein, E M., and C H Langmuir, Global correlations of ocean ndge basalt chemistry with axial depth and crustal thickness, J. Geophys. Res., 92, $8089-8115,1987$.

Kuo, B.Y., and D.W. Forsyth, Gravity anomalies of the ridge-transform system in the south Atlantic between 31 and $34.5^{\circ} \mathrm{S}$ : Upwelling centers and variations in crustal thickness, Mar. Geophys. Res, 10 , 205-232, 1988.

Leblanc, M., C. Dupuy, D. Cassard, J. Moutte, A. Nicolas, A. Prinzhofer, M. Rabinovitch, and P. Routhier, Essai sur la génèse des corps podiformes de chromite dans les péridotites ophiolitiques: Etude des chromites de Nouvelle Calédonie et comparaison avec celles de la Mediterranée orıentale, in Proceedings of Internatıonal Ophiolite Symposium, edited by A Panayiotu, pp. 691-701, Geol. Surv. Dep., Cyprus, 1980.

Lin, J., and J. Phipps Morgan, The spreading rate dependence of threedimensional mid-ocean ridge gravity structure, Geophys. Res. Lett., $19,13-16,1992$.

Lin, J., G.M Purdy, H. Schouten, J.C. Sempéré, and C. Zervas, Evidence from gravity data for focused magmatic accretion along the MidAtlantic Ridge, Nature, 344, 627-632, 1990.

Loomis, T.P., and R.R. Gottschalk, Hydrothermal origin of mafic layers in Alpinetype peridotıtes: Evidence from the Seiad Ultramafic complex, Calıfornia, U.S.A., Contrib. Mineral. Petrol., 76, 1-11, 1981.

MacDonald, K.C., D S. Scheırer, and S.M. Carbotte, Mid-ocean ridges: Discontinuties, segments and giant cracks, Science, 253, 986-994, 1991.

MacLeod, C.J , and D.A. Rothery, Ridge axıal segmentation in the Oman ophiolite: Evidence from along-strike variations in the sheeted dyke complex, in Opholites and Their Modern Oceanic Analogues, edited by L.M. Parson, B.J. Murton, and P. Browning, Geol Soc. Spec. Publ. London, 60, 39-63, 1992.

Madsen, J., R.S. Detrick, J.C. Mutter, P. Buhl, and J.A. Orcutt, A twoand three-dimensional analysis of gravity anomalies associated with the East Pacific Rise at $9^{\circ} \mathrm{N}$ and $13^{\circ} \mathrm{N}, J$. Geophys. Res., 95, 4967$4987,1990$.

Magde, L.S., R.S. Detrick, and T. Group, Crustal and upper mantle contribution to the axial gravity anomaly at the southern East Pacifique Rise, J. Geophys. Res, 100, 3747-3766, 1995.

Mainprice, D., and P.G. Silver, Interpretation of SKS-waves using samples from the subcontinental lithosphere, Phys. Earth Planet. Inter., 78, 257-280, 1993.

McKenzie, D.K., The generation and compaction of partially molten rock, J. Petrol, 25, 713-765, 1984.

Montigny, R., O. Le Mer, R. Thuizat, and H. Whitechurch, K-Ar and 40Ar/39Ar study of metamorphic rocks associated with the Oman ophiolite: Tectonic implications, Tectonophysics, 15I , 345-362, 1988.

Nicolas, A., A melt extraction model based on structural studies in mantle peridotites, J. Petrol., 27, 999-1022, 1986.

Nicolas, A., Structures in Ophiolites and Dynamics of Oceanic Lithosphere, 367 pp., Kluwer Acad., Norwell, Mass , 1989.

Nicolas, A., and F. Boudier, Mapping oceanic ridge segments in Oman ophiolites, J. Geophys. Res., 100, 6179-6197, 1995.

Nicolas, A., and B. Ildefonse, Flow mechanism and viscosity in basaltic magma chambers, Geophys. Res. Lett., 23 , 2013-2016, 1996.

Nicolas, A., and J.P. Poirier, Crystalline Plastictty and Solid State Flow in Metamorphic Rocks, 444 pp., John Wiley, New York, 1976.

Nicolas, A., and A. Prinzhofer, Cumulative or residual orıgin for the transition zone in ophiolites: Structural evidence, J. Petrol., 24, 188206, 1983.

Nicolas, A, and J.F. Violette, Mantle flow at oceanic spreading centers: Models derived from ophioltes, Tectonophysics, 81, 319-339, 1982.

Nicolas, A., G. Ceuleneer, F. Boudier, and M. Misseri, Structural mapping in the Oman ophiolites: Mantle diapirism along an oceanic ridge, Tectonophysics, 151, 27-56, 1988a. 
Nicolas, A., F. Boudier, and G. Ceuleneer, Mantle flow patterns and magma chambers at ocean ridges: Evidence from the Oman ophiolite, Mar. Geophys. Res., 9, 293-310, 1988 b.

Nicolas, A., F. Boudier, and B. Ildefonse, Dike patterns in diapirs beneath oceanic ridges: The Oman ophiolite, in Magmatic Systems, edited by M.P. Ryan, pp. 77-95, Academic, San Diego, Calif., 1994

Nicolas, A., F. Boudier, and B. Ildefonse, Variable crustal thickness in the Oman ophiolite: Implication for oceanic crust, J. of Geophys. Res., IOI, 17,941-17,950, 1996.

Niu, Y, and R. Hékinian, Spreading-rate dependence of the extent of mantle melting beneath ocean ridges, Nature, 385, 326-329, 1997.

Pallıster, J.S., and C.A. Hopson, Semail ophiolite plutonic suite: Field relations, phase variation, cryptic variation and layering, and a model of a spreading ridge magma chamber, J. Geophys. Res., 86, 2593. 2644, 1981.

Parmentier, E.M., and J. Phipps Morgan, Spreading rate dependence of three-dimensional structure in oceanic spreading centres, Nature, 348 , 325-328, 1990.

Perrin, M., M. Prevot, and F. Bruere, Rotation of the Oman ophiolite and initial location of the ridge in the hotspot reference frame Tectonophysics, 229, 31-42, 1994.

Phipps Morgan, J., E.M. Parmentier, and J. Lin, Mechanisms for the origin of mid-ocean ridge axıal topography: implications for the thermal and mechanical structure of accreting plate boundaries, $J$. Geophys. Res., 92, 12,823-12,836, 1987.

Presnall, D.C., J.R. Dixon, T.H. O'Donnell, and S.A. Dixon, Generation of mid-ocean ridge tholeiites, J. Petrol., 20, 3-35, 1979.

Prinzhofer, A., A. Nicolas, D. Cassard, J. Moutte, M. Leblanc, P. Paris, and M. Rabinovitch, Structures in the New Caledonia peridotitegabbros: Implications for oceanic mantle and crust, Tectonophysics, $69,85-112,1980$

Rabinowıcz, M., A. Nicolas, and J.L. Vigneresse, A rolling mill effect in asthenosphere beneath oceanic spreading centers, Earth Planet. Sci. Lett., 67, 97-108, 1984.

Rabinowicz, M., G. Ceuleneer, and A. Nicolas, Melt segregation and flow in mantle diapirs below spreading centers: Evidence from the Oman ophiolite, J. Geophys. Res., 92, 3475-3486, 1987.

Ravaut, P., R. Bayer, R. Hassanı, D. Rousset, and A. Al Yahya'ey, Structure and evolution of the northern Oman margin: Gravity and seismic constraints over the Zagros-Makran-Oman collision zone, Tectonophysics, 279, 253-280, 1997.

Scott, D.R., and D.J. Stevenson, A self-consistent model of melting, magma migration and buoyancy-driven circulation beneath mid-ocean ridges, J. Geophys. Res., 94, 2973-2988, 1989.

Sinton, J., Equilibration history of the basal alpine-type peridotite, Red Mountain, New Zealand, J. Petrol., I8, 216-246, 1977.

Solomon, S.C., and D.R. Toomey, The structure of mid-ocean ridges, Annu. Rev. Earth Planet. Sci., 20, 329-364, 1992.

Sotin, C., and E.M. Parmentier, Dynamical consequences of compositional and thermal density stratification beneath spreading centers, Geophys. Res. Lett., 16, 835-838, 1989.
Sparks, D.W., and E.M. Parmentier, Melt extraction from the mantle beneath spreading centers, Earth Planet. Sci. Lett., 105, 368-377, 1991.

Sparks, D.W., E.M. Parmentier, and J. Phipps Morgan, Threedimensional mantle convection beneath a segmented spreading center: implications for along-axis variations in crustal thickness and gravity, J. Geophys. Res., 98, 21,977-21,995, 1993.

Spiegelman, M., and D.P. McKenzie, Simple 2-D models for melt extraction at mid-ocean ridges and island arcs, Earth Planet. Sci. Lett., $83,137-152,1987$

Su, W., and R. Buck, Buoyancy effects on mantle flow under mid-ocean ridges, J. Geophys. Res., 98, 12,191-12,205, 1993.

Thomas, V., J.P. Pozzi and A. Nicolas, Paleomagnetic results from Oman ophiolites related to their emplacement, Tectonophysics, 151, 297-321, 1988.

Tilton, G.R., C.A. Hopson, and J.E. Wright, Uranium-led isotopic ages of the Samail ophiolite, Oman, with applications to Tethyan ocean, $J$. Geophys. Res., 86, 2763-2775, 1981.

Tolstoy, M., A.J. Harding, and J.A. Orcutt, Crustal thickness on the MidAtlantic Ridge: Bull's eye gravity anomalies and focused accretion, Science, 262, 726-729, 1993

Toomey, D.R., G.M. Purdy, S.C. Solomon, and W.S.D. Wilcock, The three-dimensional seismic velocity structure of the East Pacific Rise near latitude $9^{\circ} 30^{\prime} \mathrm{N}$, Nature, 347, 639-645, 1990.

Vera, E., J.C. Mutter, P. Buhl, J.A. Orcutt, A.J. Harding, M.E. Kappus, R.S. Detrick, and T.M. Brocher, The structure of 0- to 0.2- m.y.-old oceanic crust at $9^{\circ} \mathrm{N}$ on the East Pacific Rise from expanded spread profiles, J. Geophys. Res., 95, 15,529-15,556, 1990.

Wang, $X$., and J.R. Cochran, Gravity anomalies, isostasy, and mantle flow at the East Pacific Rise Crest, J. Geophys. Res., 98, 19,505$19,531,1993$.

Wang, X.J., J.R. Cochran, and G.A. Barth, Gravity anomalies, crustal thickness, and the pattern of mantle flow at the fast spreading East Pacific Rise, $9^{\circ}-10^{\circ} \mathrm{N}$ : Evidence for three-dimensional upwelling, $J$. of Geophys. Res., 101, 17,927-17,940, 1996.

Whitehead, J.A.J., H.J.B. Dick, and H. Schouten, A mechanism for magmatic accretion under spreading centres, Nature, 312, 146-148, 1984.

Wilson, D.S., Focused upwelling beneath mid-ocean ridges: Evidence from seamount formation and isostatic compensation of topography, Earth Planet. Sci. Lett., 113, 41-55, 1992

F. Boudier D. Jousselin, and A. Nicolas, Laboratoire de Tectonophysique, Centre National de Recherche Scientifique UMR5568, ISTEEM, Université Montpellier II, 34095 Montpellier cedex 05, France. (fran@dstu.univ-montp2.fr; jousse@dstu.univ-montp2.fr; tectono@dstu.univ-montp2.fr)

(Received October 7, 1997; revised April 6, 1998; accepted April 28, 1998.) 